\title{
Heat flow study at the Chinese Continental Scientific Drilling site: Borehole temperature, thermal conductivity, and radiogenic heat production
}

\author{
Lijuan He, ${ }^{1}$ Shengbiao Hu, ${ }^{1}$ Shaopeng Huang, ${ }^{2}$ Wencai Yang, ${ }^{3}$ Jiyang Wang, ${ }^{1}$ \\ Yusong Yuan, ${ }^{1}$ and Shuchun Yang ${ }^{1}$ \\ Received 28 January 2007; revised 25 October 2007; accepted 7 December 2007; published 23 February 2008.
}

[1] The Chinese Continental Scientific Drilling (CCSD) Project offers a unique opportunity for studying the thermal regime of the Dabie-Sulu ultrahigh-pressure metamorphic belt. In this paper, we report measurements of borehole temperature, thermal conductivity, and radiogenic heat production from the $5158 \mathrm{~m}$ deep main hole (CCSD MH). We have obtained six continuous temperature profiles from this borehole so far. The temperature logs show a transient mean thermal gradient that has increased from 24.38 to $25.28 \mathrm{~K} \mathrm{~km}^{-1}$ over a period of about 1.5 years. We measured thermal conductivities and radiogenic heat productions on more than 400 core samples from CCSD MH. The measured thermal conductivities range between 1.71 and $3.60 \mathrm{~W} \mathrm{~m}^{-1}$ $\mathrm{K}^{-1}$, and the radiogenic heat productions vary from $0.01 \mu \mathrm{W} \mathrm{m}{ }^{-3}$ to over $5.0 \mu \mathrm{W} \mathrm{m}^{-3}$, with a mean value of $1.23 \pm 0.82 \mu \mathrm{W} \mathrm{m}{ }^{-3}$ for the upper $5-\mathrm{km}$ layer of the crust. The heat productions in CCSD MH appear to be more rock-type than depth-dependent and, over the depth range of CCSD MH, do not fit the popular model of heat production decreasing exponentially with increasing depth. The measured heat flow decreases with depth from $\sim 75 \mathrm{~mW} \mathrm{~m}^{-2}$ near the surface to $\sim 66 \mathrm{~mW} \mathrm{~m}^{-2}$ at a depth of $4600 \mathrm{~m}$. High heat flow anomalies occur at $\sim 1000$ and $\sim 2300 \mathrm{~m}$, and low anomalies occur at $3300-4000 \mathrm{~m}$. A preliminary two-dimensional numerical model suggests that both radiogenic heat production and thermal refraction due to structural heterogeneity are at least partially responsible for the vertical variation of heat flow in CCSD MH.

Citation: He, L., S. Hu, S. Huang, W. Yang, J. Wang, Y. Yuan, and S. Yang (2008), Heat flow study at the Chinese Continental Scientific Drilling site: Borehole temperature, thermal conductivity, and radiogenic heat production, J. Geophys. Res., 113, B02404, doi:10.1029/2007JB004958.

\section{Introduction}

[2] An ultrahigh-pressure metamorphic (UHPM) terrain represents a geological environment where rocks of upper crust origin were exhumed back to the surface after subduction to depths greater than $100 \mathrm{~km}$ in the upper mantle. Since the discovery of coesite-bearing eclogites $[X u, 1987]$ and diamond-bearing eclogites in the region [Wang et al., 1989], the Dabie-Sulu UHPM Belt has attracted extensive interests from the Earth science community. It is regarded as the largest UHPM belt in the world [Xu et al., 1998].

[3] The Dabie-Sulu UHPM Belt was originally resulted from the collision between the Sino-Korean (or North China) Craton and the Yangtze Craton (Figure 1) in the

\footnotetext{
${ }^{1}$ Institute of Geology and Geophysics, Chinese Academy of Sciences, Beijing, China.

${ }^{2}$ Department of Geological Sciences, University of Michigan, Ann Arbor, Michigan, USA.

${ }^{3}$ Institute of Geology, Chinese Academy of Geological Sciences, Beijing, China.
}

Copyright 2008 by the American Geophysical Union. 0148-0227/08/2007JB004958\$09.00
Triassic ( 220 Ma) [Li et al., 1989a, 1989b; Hacker et al., 2000; Ratschbacher et al., 2000] and was reactivated during the Early Cretaceous by Pacific back-arc extension [Yin and Nie, 1996]. Geophysical and geochemical studies [Gao et al., 1999, 2004; Hu et al., 2007] revealed that the thickness, chemical composition, and thermal state of the lithosphere in this region experienced a dramatic transition during the Phanerozoic.

[4] Sponsored by the Ministry of Science and Technology of China and the International Continental Drilling Program, the Chinese Continental Scientific Drilling (CCSD) Project aims to investigate the deep structure of this unusual orogenic belt [Xu et al., 1998] including its geophysical characteristics. The CCSD project includes three boreholes: a $5158 \mathrm{~m}$ deep main hole (CCSD MH) and two pilot holes (CCSD PP1 and CCSD PP2) of $426 \mathrm{~m}$ and $1028 \mathrm{~m}$. CCSD $\mathrm{MH}$ is located at $34^{\circ} 24^{\prime} 36^{\prime \prime} \mathrm{N}, 118^{\circ} 40^{\prime} 12^{\prime \prime} \mathrm{E}, 17 \mathrm{~km}$ southwest of Donghai County of the Lianyungang city (Figure 1). The drilling of CCSD MH was begun on 4 August 2001 and was completed on 8 March 2005. The borehole was $85 \%$ cored [Yang et al., 2006a] and cased down to the depth of $4800 \mathrm{~m}$. 


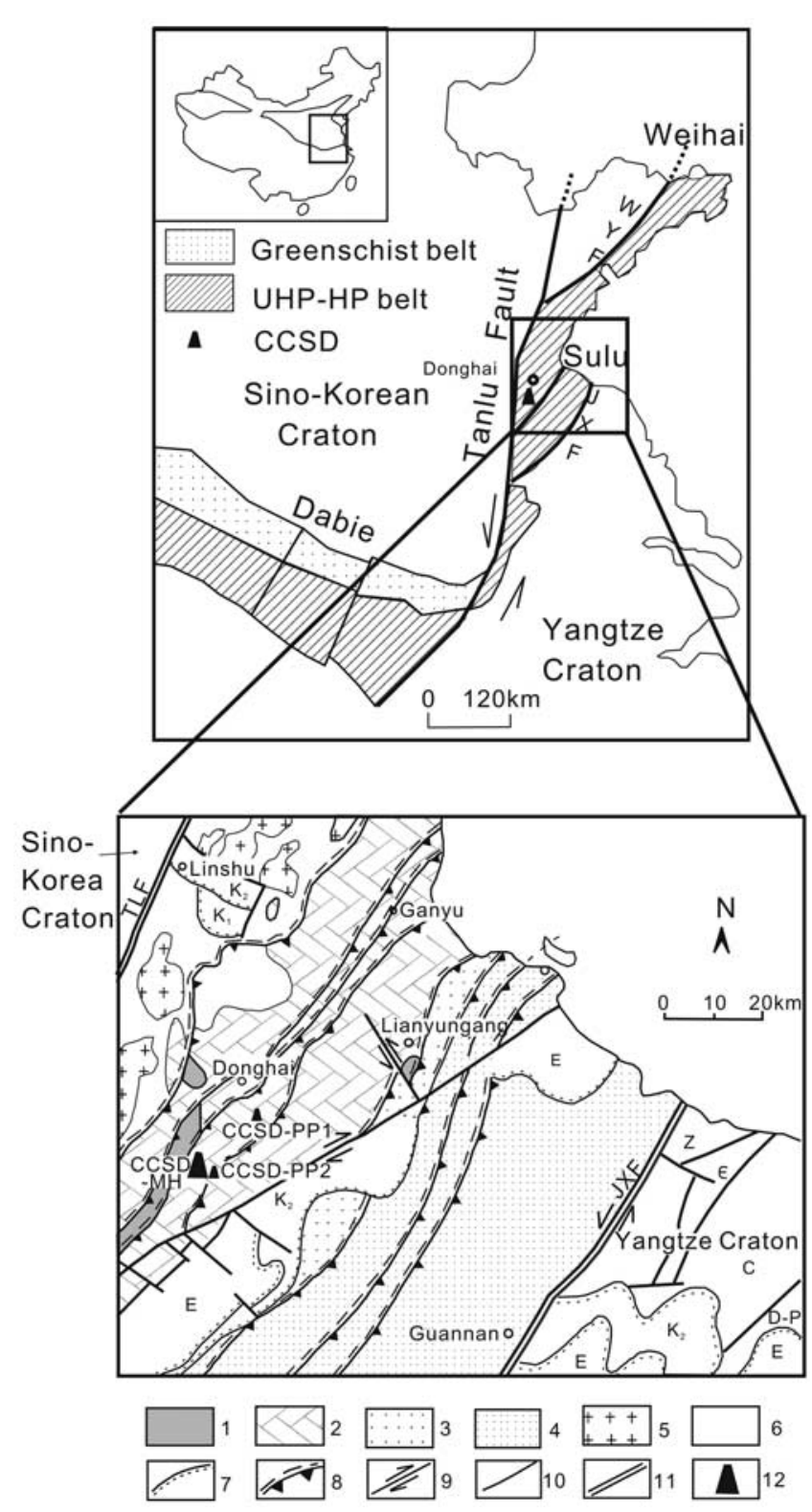

Figure 1. Tectonic setting of the Dabie-Sulu metamorphic belt and the Chinese Continental Deep Drilling site in east China (modified from Yang [2002] and Xu et al. [2003]). Legend: 1, ultrahigh-pressure metamorphic granitic gneiss overlap slice of the northern Sulu; 2, ultrahigh-pressure metamorphic supracrustal overlap slice of the northern Sulu; 3 , high-pressure and medium-temperature overlap slice of the southern Sulu; 4, high-pressure and low-temperature overlap slice of the southern Sulu; 5, Mesozoic granite; 6 , other units; 7, angular unconformity; 8 , ductile shear zone; 9, strike-slip fault; 10, fault; 11, lithospheric fault, (TLF, Tanlu Fault, JXF, Jiashan-Xiangshui Fault); 12, drilling site.

[5] One objective of the CCSD Project is to understand the crustal thermal structure of the Dabie-Sulu UHPM Belt. For this purpose, we have so far obtained six repeat temperature logs and made thermal conductivity and radiogenic heat production measurements on more than 400 core samples from CCSD MH.
[6] The main focus of this paper is on the data reduction of borehole temperature and thermophysical property measurements for the determination of heat flow from CCSD MH. A preliminary numerical model based on seismic data [Yang et al., 2006b] is constructed to explain the variation of the heat flow with depth. We also discuss the tectonic implications of the results from CCSD MH and compare them to the results from the Kola superdeep well SG-3 [Arshavskaya et al., 1987; Pribnow and Winter, 1997; Popov et al., 1999b] and the main hole of the German Continental Deep Drilling Program (KTB HB) [Clauser et al., 1997].

\section{Borehole Temperature}

\subsection{Temperature Logging}

[7] After a short stabilization period following the completion of CCSD MH on 8 March 2005, the first campaign of geophysical logging of CCSD MH was conducted between 24 and 27 March 2005. To minimize the disturbances from other logging activities, the first temperature logging was postponed for another week, to 2 April 2005 [He et al., 2006]. So far, temperature logging has been repeated on 12 April, 15 May and 15 July 2005, and 30 March and 23 September 2006.

[8] The continuous temperature logging system of platinum resistance transducer that we used was manufactured by the Robertson Geologging Ltd, UK. The response time of the sensor probe due to the thermal mass of the sensor assembly is about $2 \mathrm{~s}$. The accuracy of temperature measurement is $\pm 0.1 \mathrm{~K}$. In this project, borehole temperatures were measured always at $0.01-\mathrm{m}$ depth intervals, but the descending rate of the probe may change between 2.5 and $5.0 \mathrm{~m} \mathrm{~min}^{-1}$ for different downhole trips.

[9] Different logging rates can result in some temperature difference among the logs because of the response time of the probe. The temperature lag between two logs due to the difference in their logging rates can be estimated by the product of velocity difference, temperature gradient, and time constant of the probe [Reiter et al., 1980]. In this case, the maximum temperature difference due to different logging speeds among the six repeat logs is estimated to be approximately $0.2 \mathrm{~m} \mathrm{~K}$.

[10] In theory, the effect of the probe's thermal time constant should be removed by a deconvolution process [Nielsen and Balling, 1984; Nielsen, 1986]. However, because of the slow descending rate of the probe in our logging practice, the effect of the response time on temperature measurements is smaller than the accuracy of the sensor. Therefore, we did not apply a deconvolution filter to the temperature data. Skipping the deconvolution treatment results in a small depth offset [Beck and Balling, 1988]. The depth offset for a probe descending rate of $5 \mathrm{~m} \mathrm{~min}^{-1}$ is less than $0.1 \mathrm{~m}$.

[11] Unfortunately, the logging system could not reach the bottom of CCSD MH apparently due to the obstacle of mud in the lowest section of the borehole. The recorded maximum depth of the temperature logs is $4860 \mathrm{~m}$, corresponding to a vertical depth of $4765 \mathrm{~m}$ after well deflection correction. The maximum temperature measured is $134.5^{\circ} \mathrm{C}$ at this depth. 


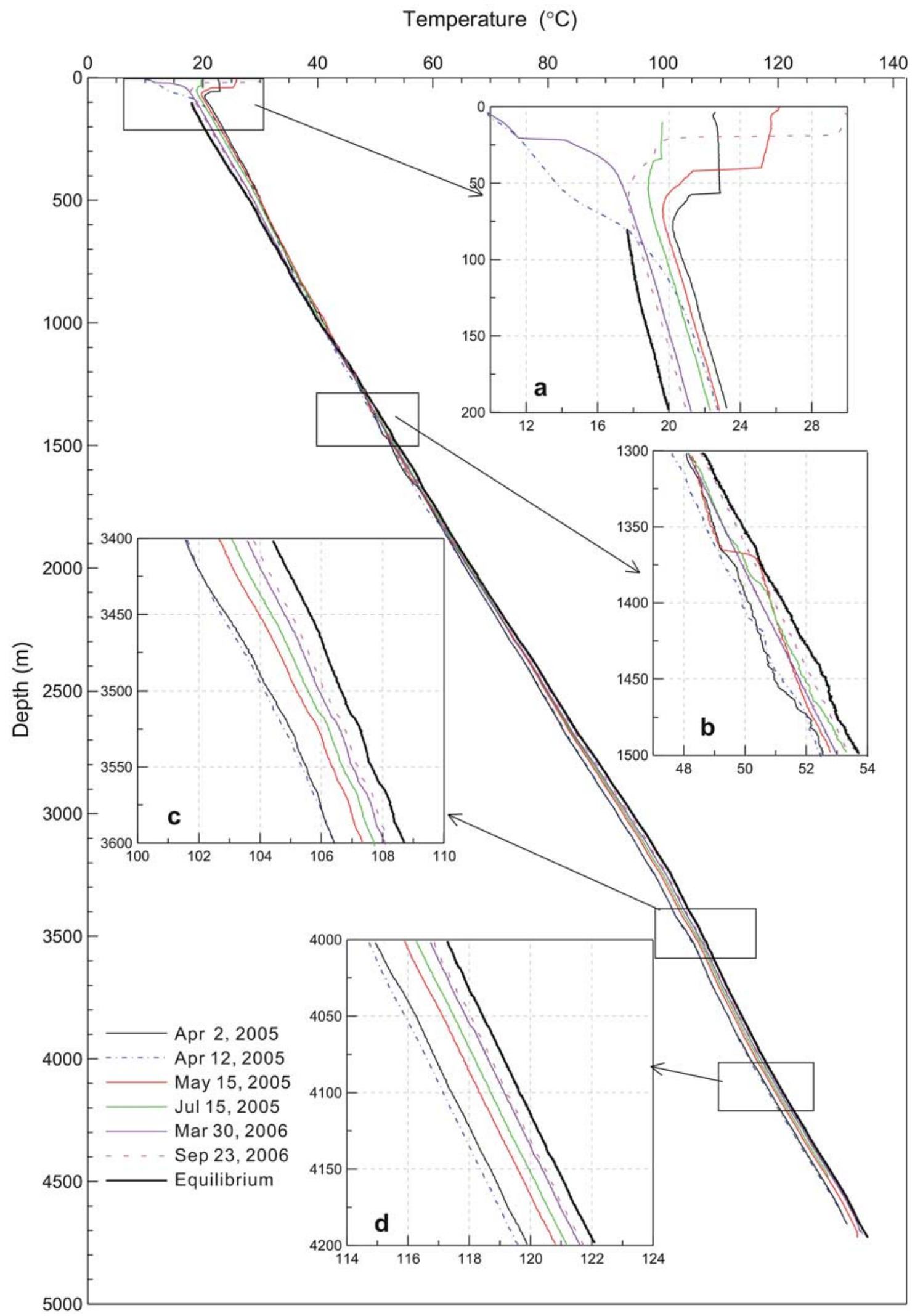

Figure 2. Temperature-depth profiles observed in CCSD MH and the estimated equilibrium temperatures. (a, b, c, and d) Enlargements of the profiles showing the differences over the four selected depth ranges. 


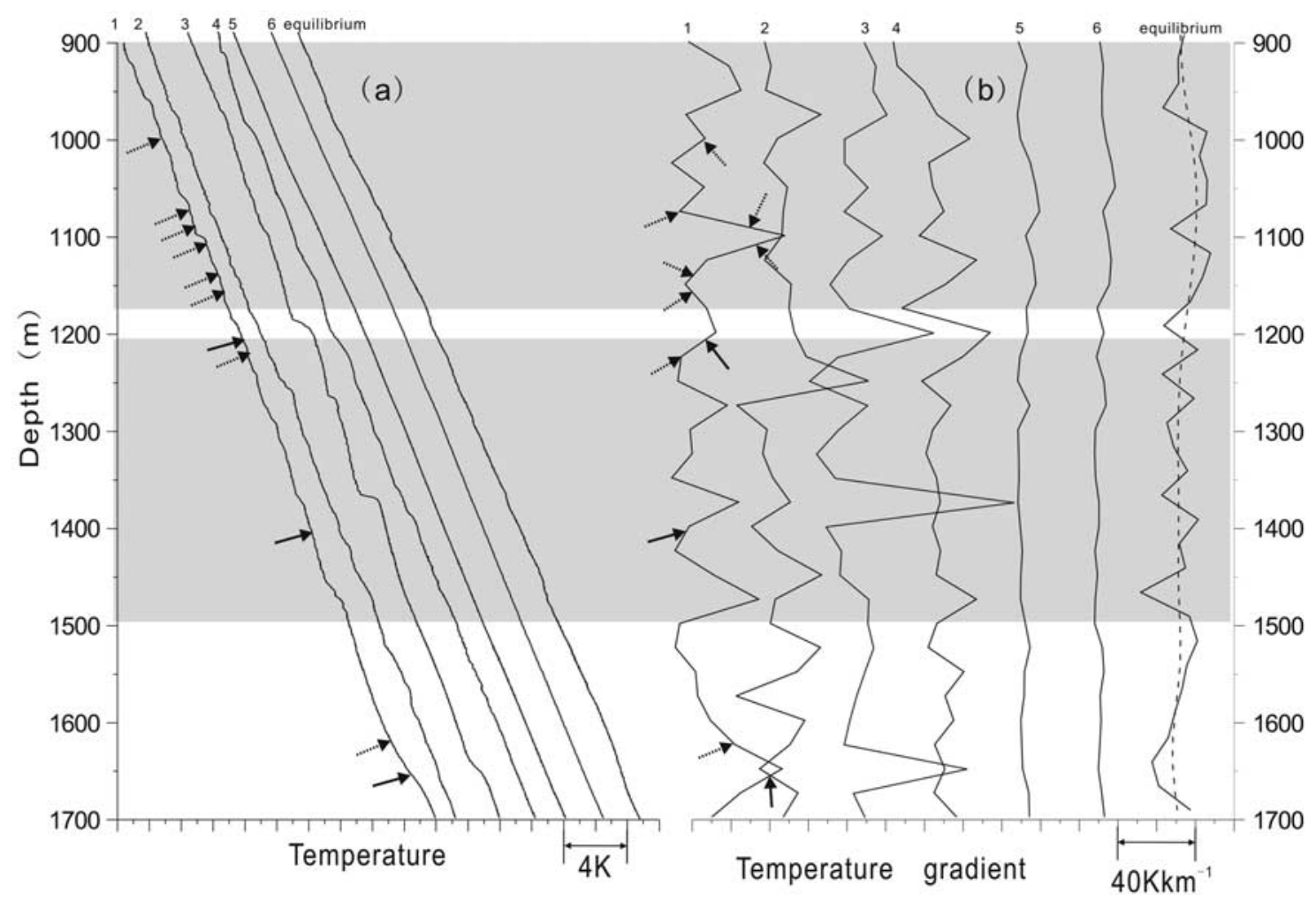

Figure 3. (a) Temperatures and (b) temperature gradients from 900 to $1700 \mathrm{~m}$. The solid arrows mark breakout sections, and the dashed arrows indicate microfactures and miniature faults. The shaded areas mark the sections where extraneous fluids were found. Temperature disturbances possibly caused by advective heat transfer were obvious in the first four measured temperature profiles but dissipated by the time of the last two. The equilibrium temperatures are extrapolated from all the temperature logs and are affected by these early disturbances. The dashed curve in Figure $3 \mathrm{~b}$ is the temperature gradient after Gaussian low-pass filtering, which is used for heat flow determination.

[12] The six temperature profiles are shown in Figure 2. Four small inserts are the enlargements of four selected depth intervals to show the differences among the profiles.

[13] The first small insert (Figure 2a) reflects the temperature variation from the surface to the depth of $200 \mathrm{~m}$. The temperatures at the depths smaller than $80 \mathrm{~m}$ changed dramatically among these profiles. Temperature changes below $80 \mathrm{~m}$ were much more regular, generally showing a good linear relationship with depth. The exact cause of the irregular temperature changes in the uppermost $80-\mathrm{m}$ segment remains unknown, given that the water level of the borehole is $\sim 20 \mathrm{~m}$. A possible interpretation is that this depth represents the maximum depth of the tundish-shaped groundwater table around the hole, which was formed when the circulation mud was pumped out.

[14] Abnormal borehole temperature variations were detected in the depth interval between 900 and $1700 \mathrm{~m}$ in the first four temperature profiles. Most of those sharp variations disappeared in the last two profiles (Figures $2 b$ and 3). Studies indicate that there exist complex brittle micro-fractures within the upper $2000 \mathrm{~m}$ of the main hole. Breakouts were found at depths 1216, 1405, 1651, and 2000 $\mathrm{m}$ [Cui et al., 2004] and cracks and $\mathrm{CH}_{4}, \mathrm{He}$, and $\mathrm{CO}_{2}$ anomalies at 476, 1007, and $1936 \mathrm{~m}$ [Luo et al., 2004]. Lots of miniature faults (see Figure 3) have been identified by
Tang [2005]. In addition, extraneous fluids were found to be added into the well mud within the sections of $891-1171 \mathrm{~m}$ and 1203-1492 m, respectively [Sun et al., 2004].

[15] Groundwater movement in fractures may greatly affect the temperature profile of a borehole. Four types of fractures have been classified with respect to their hydrothermal impacts [Lewis and Beck, 1977; Drury and Jessop, 1982; Drury et al., 1984; Beck and Balling, 1988]. One of them is the one that does not permit flow before drilling and does not allow flow after, but accepts circulation fluid during, drilling. The entry of drilling fluid of a temperature different from the formation temperature at the depth of a fracture produces a transitory thermal anomaly of relatively short duration. The effects would usually dissipate during the time required for the hole to return to conductive thermal equilibrium. The fractures in the impermeable crystalline rocks encountered by CCSD MH belong to this type. Those distinct temperature disturbances were caused by fluid from these fractures, and they were diminished by the time of the last two logs.

[16] It is obvious from the comparison of the different temperature logs that the borehole has been undergoing a thermal recovery process. Since shut-in, the upper part of the borehole has been cooling down, while the lower part has been warming up (Figure 2). This is because the upper 


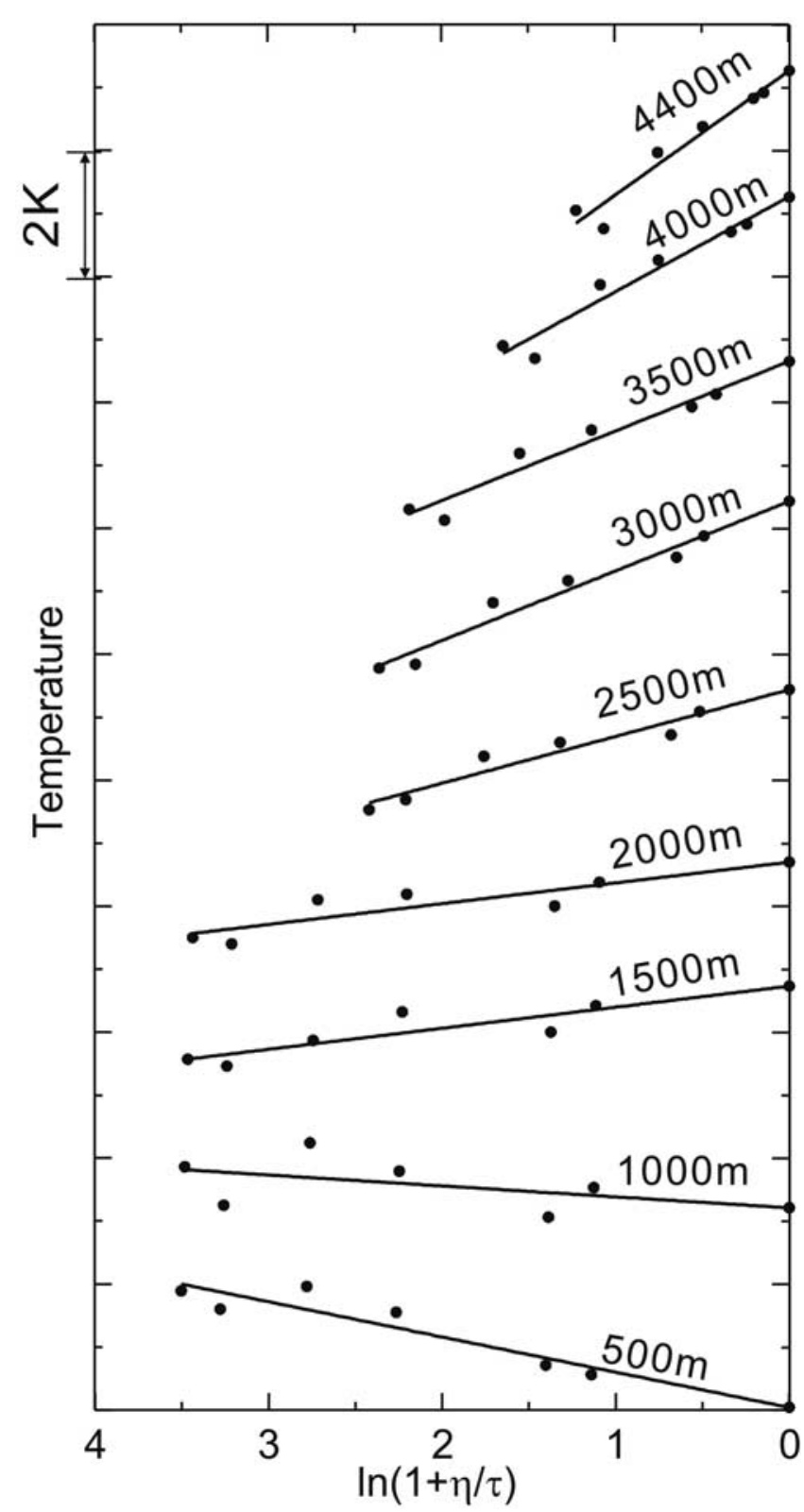

Figure 4. Temperature versus $\ln (1+\eta / \tau)$ at some sample depths of CCSD MH. The interceptions are the estimates of the equilibrium formation temperatures at the corresponding depths.

part of the borehole had been heated and the lower part has been cooled by fluid circulation during drilling. Apparently, borehole temperatures of CCSD $\mathrm{MH}$ are still recovering from the drilling perturbations. A shallow borehole requires a relatively shorter time to return to thermal equilibrium. But it will take years for a deep borehole such as CCSD MH to return to thermal equilibrium because of the longer drilling time and hence the greater thermal perturbation.

\subsection{Correction for Drilling Perturbation}

[17] For a reliable determination of heat flow, determination of the equilibrium temperatures is essential. Repeat temperature logs from a deep borehole that is still recover- ing from drilling disturbance allow its equilibrium temperatures to be constrained. It has been shown [Bullard, 1947; Lachenbruch and Brewer, 1959] that at a given depth, the equilibrium temperature $T_{e q}$ can be estimated by the relationship

$$
T=T_{e q}+s \cdot \ln \left(1+\frac{\eta}{\tau}\right)
$$

where $T$ is the measured temperature at a particular time, $\eta$ is the time elapsed since the drill bit first reached the given depth until the drilling operation ceased, $\tau$ is the time between the drilling completion and the time of the temperature measurement, and $s$ is a constant for the given depth but may be different at different depths. We have calculated $\eta$ and $\tau$ based on CCSD MH daily drilling report, which is accessible at the International Continental Scientific Drilling Program Web site (http:/www.icdp-online.de/ contenido/icdp/front_content.php?idart=1288).

[18] Figure 4 illustrates the application of equation (1) for estimating equilibrium temperatures based on the repeat temperature logs. It also shows the variations of temperature with time at different depths. The temperatures above $1500 \mathrm{~m}$ have decreased with time, but those below this depth have increased.

[19] Among the six logs from CCSD MH, the first two temperature profiles are the most unstable. They were logged shortly after shut-in, and the time difference between the first two logs is only $10 \mathrm{~d}$. It is possible that the inclusion of the first two logs distorts the estimated equilibrium formation temperatures. To examine their possible influence to the estimates, we have compared the equilibrium temperatures derived from all six logs and those from only the four later logs. The results show that the exclusion of the first two logs from the estimation process does not make a significant difference to the overall results. Therefore, all six logs are used to determine the equilibrium temperatures (dark solid line in Figure 2) in this study, except for the greatest depths below $4485 \mathrm{~m}$. The vertical logging depth for the forth $\log$ is $4485 \mathrm{~m}$, which is the shallowest among the six logs. The equilibrium temperatures below $4485 \mathrm{~m}$ are extrapolated from the five logs available.

[20] Prior to the commencement of the drilling of the main hole, temperature logging in the two pilot holes were conducted shortly after their completion in 1997 and 1999 , respectively, aiming for temperature prediction of the main hole [Wang et al., 2001a, 2001b]. We were able to relog CCSD PP2 (about $400 \mathrm{~m}$ away from CCSD MH) down to the depth of $900 \mathrm{~m}$ six years later on 17 May 2005 with the same logging system as we used for CCSD MH. Unfortunately, the pilot hole CCSD PP1 has been turned into a groundwater production hole and cannot be measured at present. Figure 5a shows the two logs from CCSD PP2 and the 23 September $2006 \log$ together with the estimated equilibrium temperatures for the upper $900 \mathrm{~m}$ of CCSD $\mathrm{MH}$. Figure $5 \mathrm{~b}$ shows the residual temperatures from removing a common linear trend $(T=0.02494 * z+15.3$, where $z$ is depth in $\mathrm{m}$ ) from all the four profiles. Although the observed temperatures from the shallow part of CCSD 

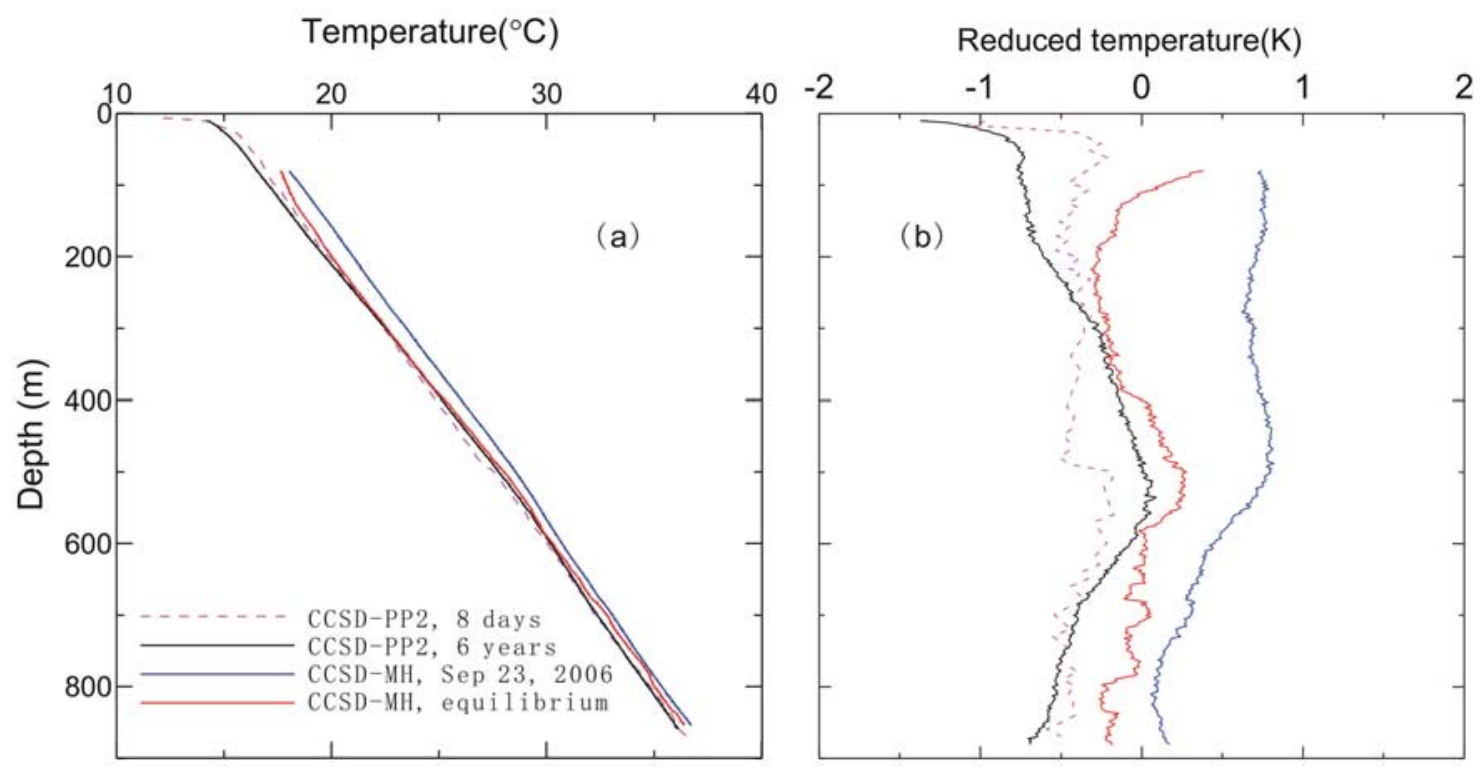

Figure 5. (a) Comparisons of the temperature logs from the pilot borehole CCSD PP2 and from the uppermost section of CCSD MH. (b) Residual temperatures after the removal of a common linear trend. Note that the recently measured temperatures from CCSD MH are higher than those from CCSD PP2. However, a good match can be seen between the estimated equilibrium temperatures in CCSD MH and the temperatures in CCSD PP2 obtained 6 years after the completion of drilling.

MH are slightly higher than those from CCSD PP2, the estimated CCSD MH equilibrium temperatures match the CCSD PP2 temperatures quite well, indicating that the estimated equilibrium temperatures are reliable.

\subsection{Temperature Gradient}

[21] Since shut-in, the magnitude of the temperature gradient fluctuation in CCSD MH has decreased progressively. In the meantime, the overall temperature gradient has increased systematically. Shown in Figure 6 and Table 1 for

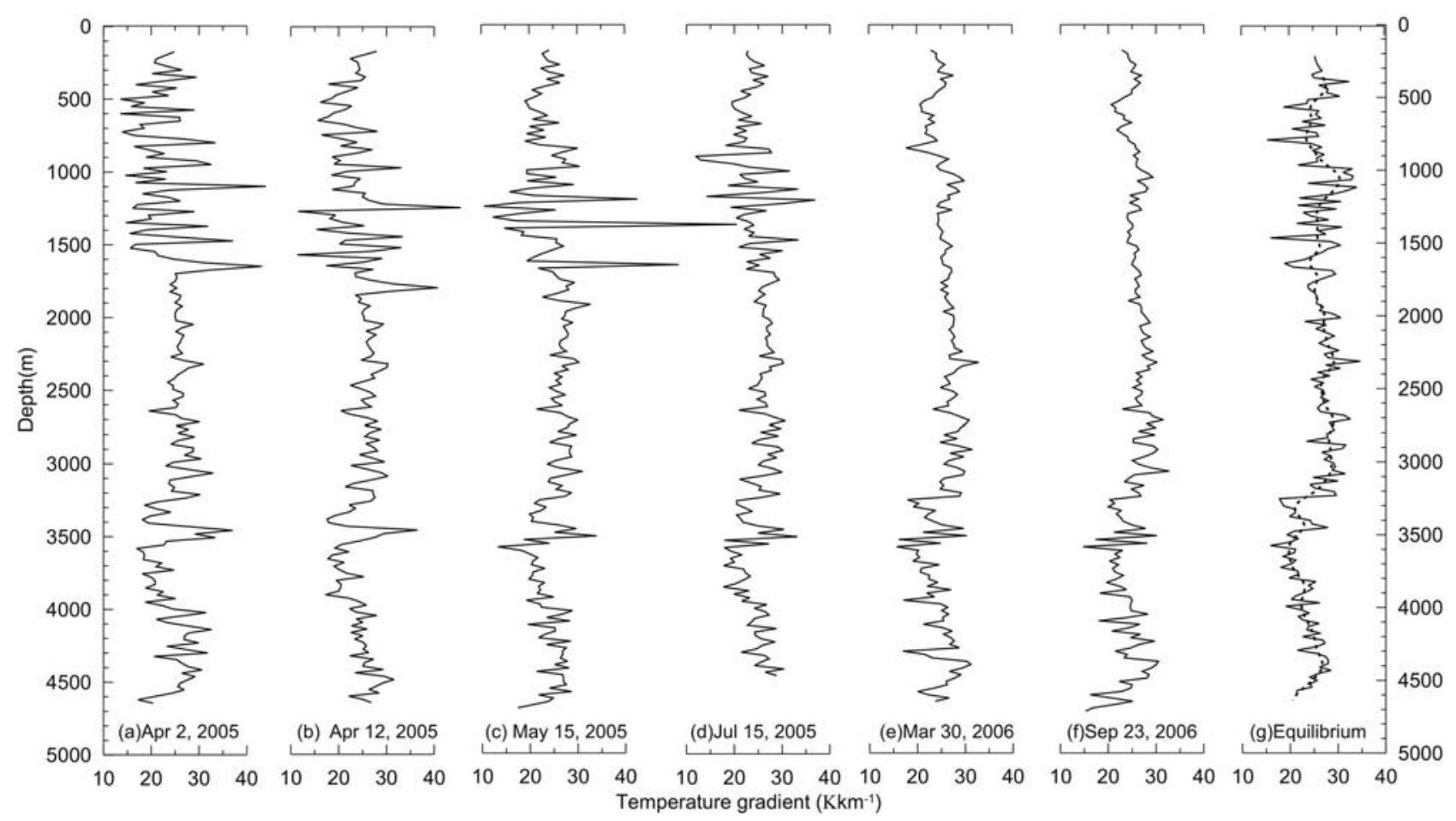

Figure 6. Variation of temperature gradient with time in CCSD MH. Logging dates are marked beneath the profiles. The dashed curve in Figure $6 \mathrm{~g}$ is the Gaussian filter smoothened version of the estimated temperature gradient profile used in the heat flow calculation of the current study. 
Table 1. Average Temperature Gradients for the Six Logs and for the Estimated Equilibrium Temperature Profile

\begin{tabular}{lcc}
\hline \multicolumn{1}{c}{$\begin{array}{c}\text { Temperature } \\
\text { Log }\end{array}$} & $\begin{array}{c}\text { Temperature Gradient, } \\
\mathrm{K} \mathrm{km}^{-1}\end{array}$ & $\begin{array}{c}\text { Standard Deviation, } \\
\mathrm{K} \mathrm{km}^{-1}\end{array}$ \\
\hline 2 Apr 2005 & 24.38 & 5.02 \\
12 Apr 2005 & 24.60 & 4.68 \\
15 May 2005 & 24.66 & 5.30 \\
15 Jul 2005 & 24.69 & 3.73 \\
30 Mar 2006 & 25.24 & 3.07 \\
23 Sep 2006 & 25.28 & 2.85 \\
Estimated equilibrium & 25.31 & 2.60 \\
\hline
\end{tabular}

comparison are the temperature gradients, derived using linear least squares regression [Powell et al., 1988] at depth intervals of $25 \mathrm{~m}$ for the six temperature logs and for the estimated equilibrium temperature profile. Large fluctuations in temperature gradient were observed in the $900-$ $1700 \mathrm{~m}$ depth range in earlier logs. The fluctuations in this depth range were most pronounced in the third $\log$ (15 July 2005, Figure 6c), and diminished progressively in subsequent logs. The temporal evolution of these anomalies can be attributed to the closure of microcracks as discussed in section 2.1

[22] Another zone of abnormal temperature gradient was observed at around $3500 \mathrm{~m}$. Although present in all six logs, the anomalies around this depth have also diminished with

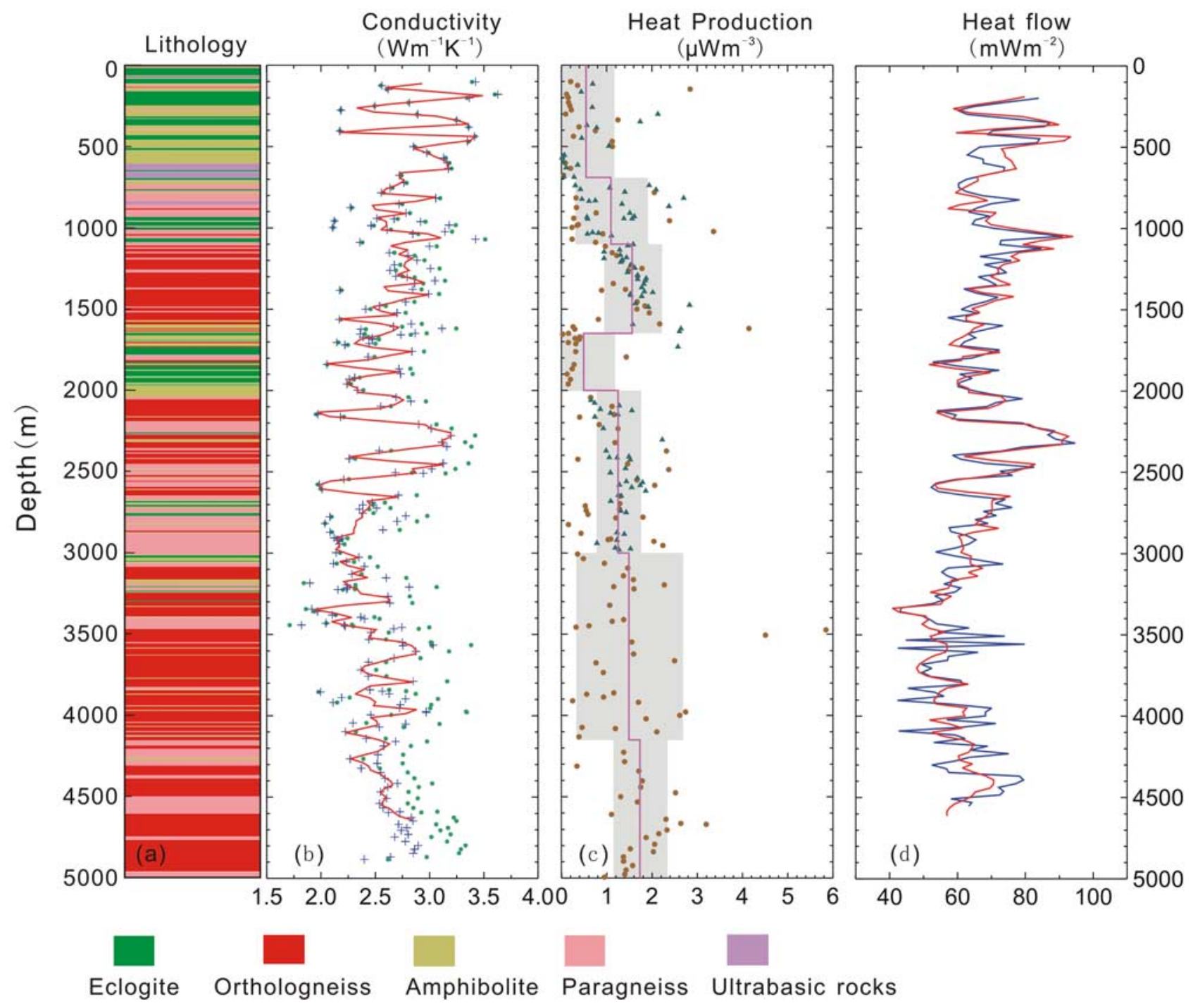

Figure 7. Variations of (a) lithology, (b) thermal conductivity, (c) heat production, and (d) heat flow in CCSD MH. Measured thermal conductivities are shown as dots, and corrected values are shown as crosses in Figure $7 \mathrm{~b}$ where the solid line connects the harmonic means at depth intervals of $25 \mathrm{~m}$. The heat production rates shown in Figure 7c include the new measurements of this study (solid dots) and the measurements from previous studies (triangles) [Liu et al., 2004, 2005a, 2005b; Zhang et al., 2004; Xue and Liu, 2005]. The vertical line segments in Figure 7c represent the average heat productions for different layers, and the grey boxes represent their standard deviations. The heat flow profiles calculated from the sixth $\log$ and from the estimated equilibrium temperatures are shown in blue and red, respectively, in Figure 7d. 

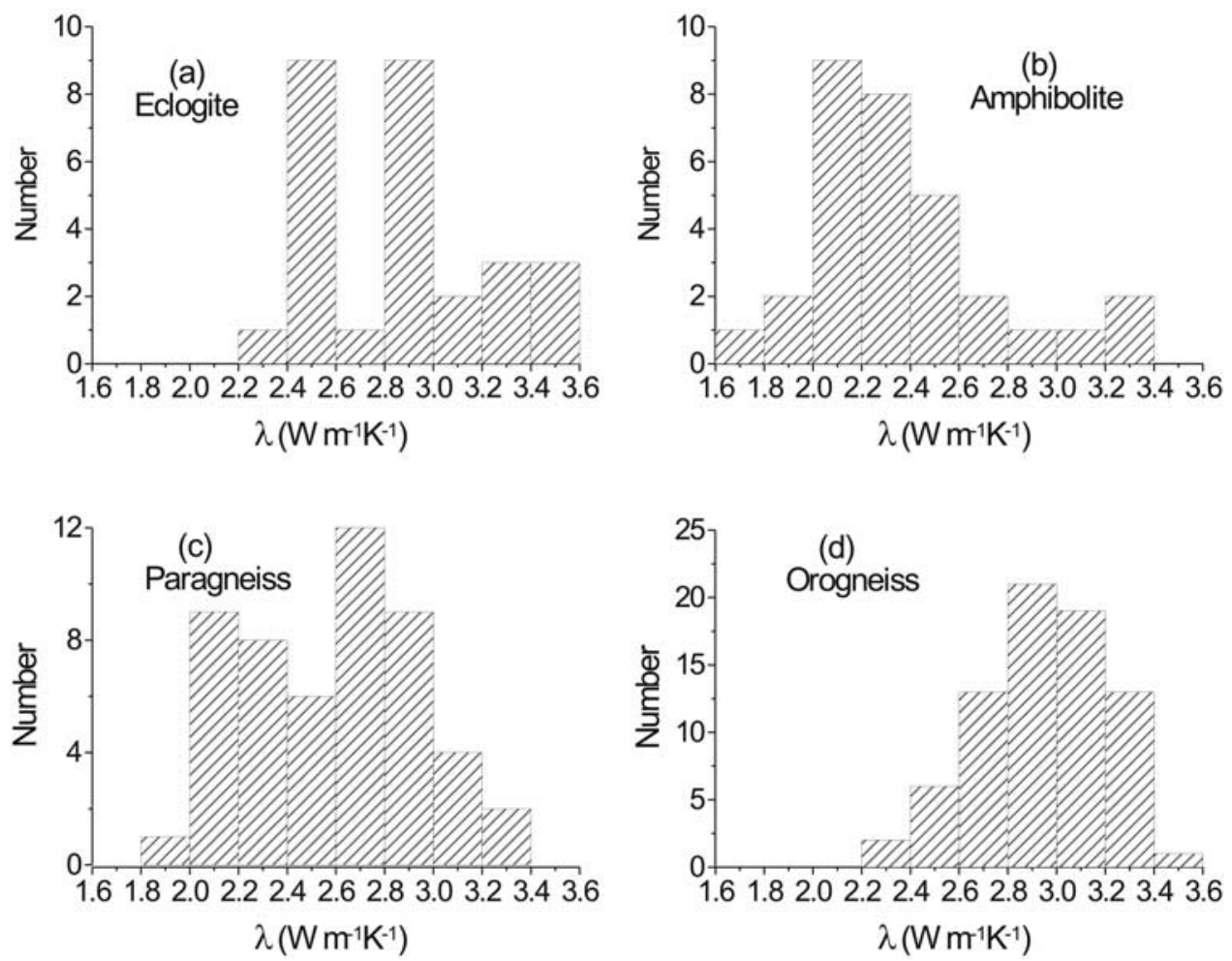

Figure 8. Histograms of thermal conductivity $(\lambda)$ measurements of core samples from CCSD MH.

time. There might have been some fluid flow around this depth, yet their impact on the temperature gradient has also been weakening.

[23] The general patterns of temperature gradient variation with depth are similar for all the profiles except for the $900-1700 \mathrm{~m}$ depth interval (Figures 3 and $6 \mathrm{a}-6 \mathrm{f}$ ). Since the equilibrium temperatures are extrapolated from all the six logs, the temperature gradient profile derived from the estimated equilibrium temperatures may inherit to certain extent the anomalies of the earlier logs. These disturbances are temporal and can be suppressed by Gaussian low-pass filtering. The temperature gradient after the filtering (dashed curve in Figure $6 \mathrm{~g}$ ) is used for heat flow determination.

[24] The average temperature gradient of the whole hole increased with time from $24.38 \mathrm{~K} \mathrm{~km}^{-1}$ of the first (2 April 2005) $\log$ to $25.28 \mathrm{~K} \mathrm{~km}^{-1}$ of the sixth (23 September 2006) $\log$, with the corresponding standard deviation decreasing from 5.02 to $2.85 \mathrm{~K} \mathrm{~km}^{-1}$. The final equilibrium temperature gradient in CCSD MH is estimated to be $25.31 \pm$ $2.60 \mathrm{~K} \mathrm{~km}^{-1}$.

\section{Thermal Conductivity}

\subsection{Sample Measurements}

[25] In this study, we collected 198 core samples systematically from CCSD MH for thermal conductivity measurements. The thermal conductivities were measured with the optical scanning technology [Popov et al., 1999a]. The apparatus was manufactured by the German TCS Company with an accuracy $\pm 3 \%$ for the measurement range from 0.2 to $25 \mathrm{~W} \mathrm{~m}^{-1} \mathrm{~K}^{-1}$. It scans the plane or cylindrical surface of the samples with a focused, mobile and continuously operated heat source in combination with infrared temper- ature sensors. The determination of thermal conductivity values is based on the comparison of excess temperatures of standard samples (having a known thermal conductivity) with excess temperatures of one or more unknown samples under heating by the movable concentrated heat source. $\mathrm{Ou}$ et al. [2004] and Wu et al. [2005] measured the thermal conductivities of the same core samples from the $0-2000 \mathrm{~m}$ of CCSD MH using the half-space line apparatus, and their published conductivity values of orthogneiss are 2.91 and $2.96 \mathrm{~W} \mathrm{~m}^{-1} \mathrm{~K}^{-1}$, respectively, consistent with our result of $2.95 \mathrm{~W} \mathrm{~m}^{-1} \mathrm{~K}^{-1}$.

[26] The collected core samples include all the rock types (orthogneiss, paragneiss, eclogites, amphibolite, and ultramafic rocks) encountered by CCSD MH (Figure 7a). The measured thermal conductivity values range from 1.71 to $3.60 \mathrm{~W} \mathrm{~m}^{-1} \mathrm{~K}^{-1}$ with a mean of $2.72 \pm 0.40 \mathrm{~W} \mathrm{~m}^{-1} \mathrm{~K}^{-1}$ (Figure 8). The average thermal conductivities of different rock types are listed in Table 2.

[27] Besides the mineral composition or rock type, the thermal conductivity of rocks can be influenced by other factors such as pressure, temperature, porosity, and water

Table 2. Thermal Conductivities of the Main Rock Types in CCSD MH

\begin{tabular}{lcccc}
\hline Rock Type & Samples & $\begin{array}{c}\text { Minimum, } \\
\mathrm{W} \mathrm{m}^{-1} \mathrm{~K}^{-1}\end{array}$ & $\begin{array}{c}\text { Maximum, } \\
\mathrm{W} \mathrm{m}^{-1} \mathrm{~K}^{-1}\end{array}$ & $\begin{array}{c}\text { Mean } \pm \mathrm{SD} \text {, } \\
\mathrm{W} \mathrm{K}^{-1}\end{array}$ \\
\hline Eclogite & 28 & 2.20 & 3.60 & $2.87 \pm 0.38$ \\
Amphibolite & 31 & 1.71 & 3.36 & $2.37 \pm 0.37$ \\
Paragneiss & 51 & 1.97 & 3.24 & $2.59 \pm 0.34$ \\
Orthogneiss & 75 & 2.22 & 3.42 & $2.95 \pm 0.26$ \\
Serpentinite & 2 & 2.74 & 3.20 & $2.97 \pm 0.33$ \\
\hline
\end{tabular}


saturation [Pribnow et al., 1996]. Given that all our core samples are metamorphic rocks with low porosities $(<3 \%)$ [Niu et al., 2004], we did not make water saturation correction for our sample measurements. The pressure effect is less than $1 \%$ according to our estimates based on the equation of [Seipold and Huenges, 1998] and is not described in detail here. We focus our thermal conductivity correction effort only on the temperature effect.

\subsection{Temperature Effect}

[28] It has long been known that thermal conductivity is a function of temperature. From room temperature to a few hundred degrees Celsius, the thermal conductivity decreases with increasing temperature for a wide range of crustal rocks. Sass et al. [1992] used the data of Birch and Clark [1940] to develop the following empirical relations for the thermal conductivity as a function of temperature $\lambda(T)$

$$
\lambda(0)=\lambda(25)\{1.007+25[0.0037-0.0074 / \lambda(25)]\}
$$

and

$$
\lambda(T)=\lambda(0) /\{1.007+T[0.0036-0.0072 / \lambda(0)]\},
$$

where $T$ is in situ formation temperature in ${ }^{\circ} \mathrm{C}, \lambda(0)$ and $\lambda(25)$ are thermal conductivities at 0 and $25^{\circ} \mathrm{C}$, respectively, in $\mathrm{W} \mathrm{m} \mathrm{m}^{-1} \mathrm{~K}^{-1}$.

[29] Sass et al. [1992] tested the generality of equation (2) and (3) by applying them to a quite independent data set from the Jemez Mountains, New Mexico, ranging in composition from felsic gneiss to amphibolite. These two empirical relations were used to correct all room temperature values of crystalline rocks from the scientific well in Cajon Pass, California [Sass et al., 1992]. The Sass et al. [1992] relations are fairly close to those derived by Popov et al. [1999b], who used the equation of Rybach and Buntebarth [1982]: $\lambda(T)=\lambda\left(T_{0}\right) /\left[1+\gamma\left(T-T_{0}\right)\right]$, where $T_{0}$ is room temperature and $\gamma$ is a constant coefficient. In their heat flow study of the Kola superdeep well SG-3, Popov et al. [1999b] used $\gamma=(4.6$ to 5.7$) \times 10^{-4} \mathrm{~K}^{-1}$ for amphibolite and $\gamma=(9.3$ to 10.8$) \times 10^{-4} \mathrm{~K}^{-1}$ for gneiss.

[30] In this study, we employ Equations (2) and (3) to correct the thermal conductivity measurements from CCSD $\mathrm{MH}$ samples for the temperature effect. The temperatures used in the correction are the estimated equilibrium temperatures as discussed in section 2.2. The maximum correction is about $14 \%$ for deep samples from CCSD MH. The corrected thermal conductivities are shown in Figure $7 \mathrm{~b}$.

\section{Radiogenic Heat Production}

\subsection{Sample Measurements}

[31] We have measured concentrations of radioactive heat producing elements uranium, thorium, and potassium on 149 core samples from CCSD MH, at depth intervals of around $30 \mathrm{~m}$, to determine heat production. The uranium and thorium concentrations were measured using inductively coupled plasma-mass spectrometry (ICP-MS), whereas the potassium concentrations by atomic absorption spectroscopy.
[32] The radiogenic heat productions were calculated with the formula developed by Rybach [1988]:

$$
A=10^{-5} \rho\left(9.52 C_{u}+2.56 C_{T h}+3.48 C_{k}\right),
$$

where $A$ is heat production in $\mu \mathrm{W} \mathrm{m}^{-3}, \rho$ is density in $\mathrm{kg} \mathrm{m}^{-3}$, $C_{\mathrm{u}}$ and $C_{\mathrm{Th}}$ are uranium and thorium concentrations in ppm, respectively, and $C_{\mathrm{k}}$ is potassium concentration in percentage.

[33] We combine the 149 new heat production measurements and 106 measurements from previous studies [Liu et al., 2004; Zhang et al., 2004; Xue and Liu, 2005; Liu et al., $2005 \mathrm{a}, 2005 \mathrm{~b}]$. The measured heat production for CCSD $\mathrm{MH}$ ranges from 0.01 to $5.85 \mu \mathrm{W} \mathrm{m}{ }^{-3}$, with a mean of $1.23 \pm 0.82 \mu \mathrm{W} \mathrm{m}{ }^{-3}$.

\subsection{Heat Production Versus Rock Types}

[34] Different rock types generally have their characteristic heat productions. Figure 9 shows the frequency distributions of the measured heat production rates for eclogite, amphibolite, paragneiss and orthogneiss rock samples from CCSD MH. Additionally, three peridotite core samples have been measured and found almost completely depleted in the heat producing elements. The mean values for different rock types are listed in Table 3. Among the major rock types encountered in CCSD $\mathrm{MH}$, high heat productions were observed for orthogneiss and paragneiss, and relatively lower values for eclogite and amphibolite. The mean of the three peridotite measurements is $0.01 \mu \mathrm{W} \mathrm{m} \mathrm{m}^{-3}, 2$ orders of magnitude lower than the other rock types.

[35] Geochemical evidence suggests that a large volume of continental materials (thickness $>4.5 \mathrm{~km}$ ) in the Sulu area had experienced deep subduction and ultrahigh-pressure metamorphism before they were returned to the earth's surface [Liu et al., 2005a]. On the basis of their analysis of major and trace element compositions, Liu et al. [2005b] showed that the protoliths of the paragneisses originated from sedimentary rocks (or metamorphic sedimentary rocks) on the passive continental margins of the subducted portion of the Yangtze Craton. Hence, the Paleozoic and early Proterozoic formations on the Yangtze Craton can be taken as their protolith, which is characterized by a heat production of $1.96 \mu \mathrm{W} \mathrm{m} \mathrm{m}^{-3}$, with a $\mathrm{Th} / \mathrm{U}$ ratio of 2.93 [Wang et al., 1989]. In contrast, the average heat production of the paragneiss samples from CCSD MH is $1.37 \mu \mathrm{W} \mathrm{m}^{-3}$ and the $\mathrm{Th} / \mathrm{U}$ ratio is 7.8 , suggesting substantial depletion of uranium due to the ultrahigh-pressure metamorphism.

[36] On the basis of major and trace element compositions, Liu et al. [2005b] suggest that some orthogneiss samples from CCSD MH are characterized by A-type granite protolith formed in intraplate tectonic settings while others are characterized by volcanic arc granites formed in volcanic arc settings. The average heat production of the orthogneiss is $1.65 \mu \mathrm{W} \mathrm{m} \mathrm{m}^{-3}$, which is $34 \%$ lower than that of the granite $\left(2.5 \mu \mathrm{W} \mathrm{m}^{-3}\right)$ in the Yangtze Craton [Wang et al., 1989].

[37] The chemical characteristics of the eclogite in this region have an affinity to continental basalts [Zhang et al., 2004]. The average heat production of the eclogite from CCSD $\mathrm{MH}$ is $0.42 \mu \mathrm{W} \mathrm{m} \mathrm{m}^{-3}, 21 \%$ lower than the heat production of the basalt in the North China Craton $\left(0.53 \mu \mathrm{W} \mathrm{m}^{-3}\right)$ [Chi and Yan, 1998]. 

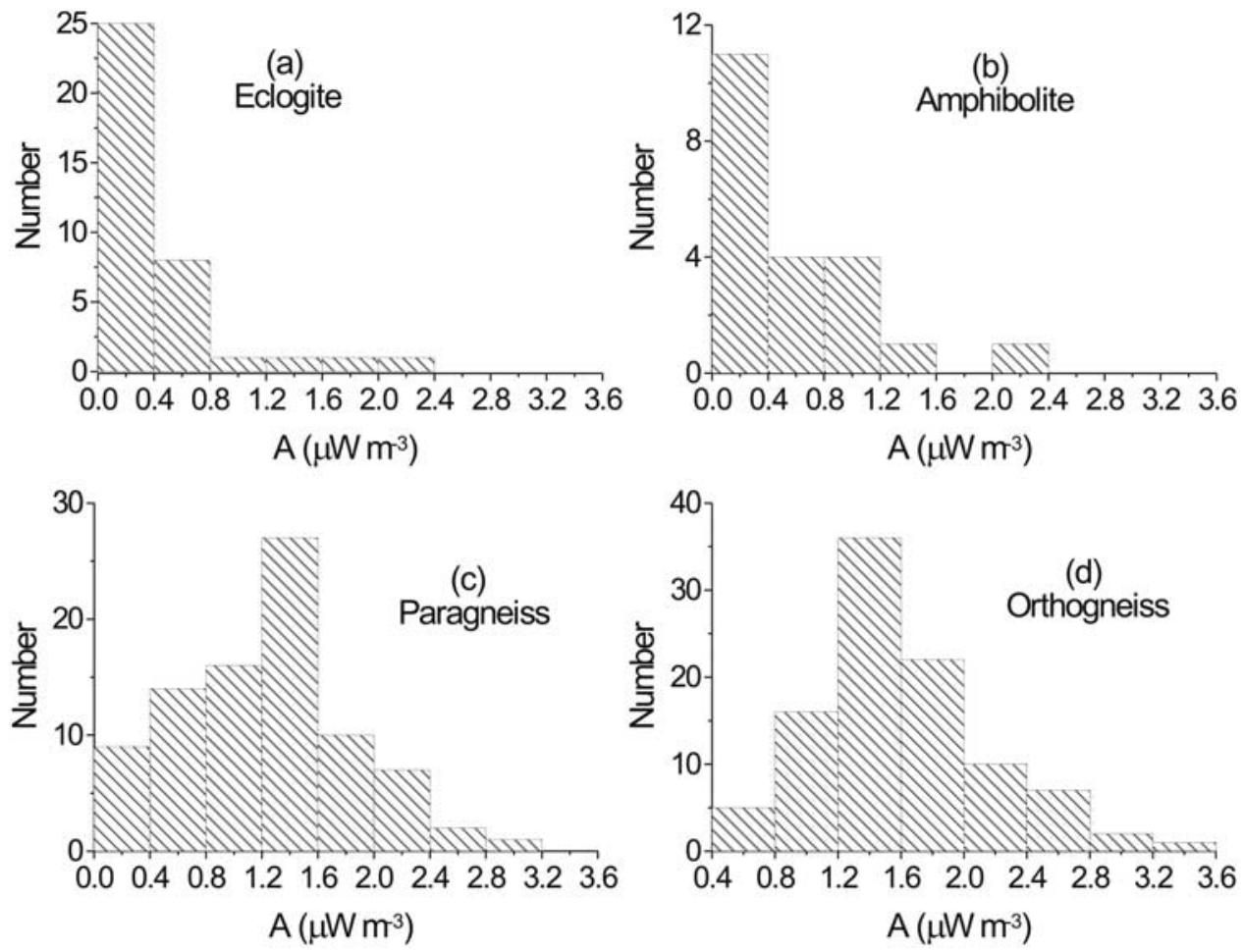

Figure 9. Histograms of heat production rates (A) of core samples from CCSD MH.

[38] Generally, our results show that the metamorphic rocks in the Dabie-Sulu UHPM Belt are 21-34\% lower in heat production than their protoliths, due to the depletion of $\mathrm{U}$ during the process of ultrahigh-pressure metamorphism.

\subsection{Heat Production Versus Depth}

[39] The average heat production of CCSD $\mathrm{MH}$ rock samples is $1.23 \mu \mathrm{W} \mathrm{m} \mathrm{m}^{-3}$. The distribution of heat production with depth is shown in Figure $7 \mathrm{c}$ where the vertical lines show the average heat production for several depth intervals corresponding to major lithologic units. CCSD $\mathrm{MH}$ can be divided into two sections at the depth of around $1650 \mathrm{~m}$; each section exhibits an increasing trend of heat production with depth. The variation of the measured heat production in the upper $2000 \mathrm{~m}$ is consistent with the result of the natural Gamma logging [Pan et al., 2006].

[40] The distribution of heat production in the crust is a subject of debate. The most well-known model assumes that the radiogenic heat production of the crustal rocks decreases exponentially with depth [Lachenbruch, 1968, 1970]. However, many studies have called this model into question [Jaupart and Mareschal, 2003]. The heat production often changes in a stepwise fashion across lithological boundaries [Pribnow and Winter, 1997; Brady et al., 2006]. In the upper crust, the heat production tends to first increase then decrease with depth [Hart et al., 1981; Nicolaysen et al., 1981; Ashwal et al., 1987; Kremenetsky et al., 1989; Ketcham, 1996]. In cases where the heat production is seen to decrease downward, errors in heat production and/or depth determinations are often too large to allow reliable tests of the exponential model [Swanberg, 1972; Swanberg and Blackwell, 1973; Nicolaysen et al., 1981; Verdoya et al., 1998]. Our heat production data indicate that the exponential heat production model is not applicable to the DabieSulu UHPM Belt. Our data show a clear lithological dependence of the heat production, as shown in the German KTB deep borehole [Pribnow and Winter, 1997].

[41] In the Dabie-Sulu UHPM Belt, the modern-day uppermost crust has experienced deep subduction, ultrahigh-pressure metamorphism, and rapid exhumation [Liu et al., 2005a]. The original strata sequence at the lower crust level during the UHP metamorphism could have been turned upside down when the subducted slab were exhumed in the setting of an orogenic belt. Evidence from mineralogical composition [Zhang et al., 2004], Pb and oxygen isotope data [Dong et al., 2006], and the lineation direction and angles of foliation [You et al., 2004] suggest that the upper and lower sections, divided at the depth of $\sim 1650 \mathrm{~m}$,

Table 3. Mean heat production rates of Different Rock Types in CCSD MH

\begin{tabular}{llccrrrr}
\hline Rock Type & $\mathrm{N}$ & $\rho, \mathrm{kg} \mathrm{m}^{-3}$ & $\mathrm{Th}, \mathrm{ppm}$ & $\mathrm{U}, \mathrm{ppm}$ & $\mathrm{K}, \%$ & \multicolumn{1}{c}{$\mathrm{Th} / \mathrm{U}$} \\
\hline Eclogite & 37 & 3272 & $2.58 \pm 3.88$ & $0.41 \pm 0.40$ & $0.77 \pm 0.71$ & 6.3 & $0.42 \pm 0.46$ \\
Amphibolite & 21 & 2965 & $3.26 \pm 3.81$ & $0.75 \pm 1.11$ & $1.55 \pm 0.67$ & $0.61 \pm 0.55$ \\
Peridotite & 3 & 2981 & $0.02 \pm 0.01$ & $0.01 \pm 0.01$ & $0.01 \pm 0.01$ & 1.4 & $0.01 \pm 0.13$ \\
Paragneiss & 88 & 2727 & $10.93 \pm 13.9$ & $1.40 \pm 0.93$ & $2.76 \pm 1.12$ & 7.8 & $1.37 \pm 1.13$ \\
Orthogneiss & 100 & 2665 & $13.06 \pm 6.19$ & $1.71 \pm 1.30$ & $3.88 \pm 0.99$ & 7.6 \\
\hline
\end{tabular}




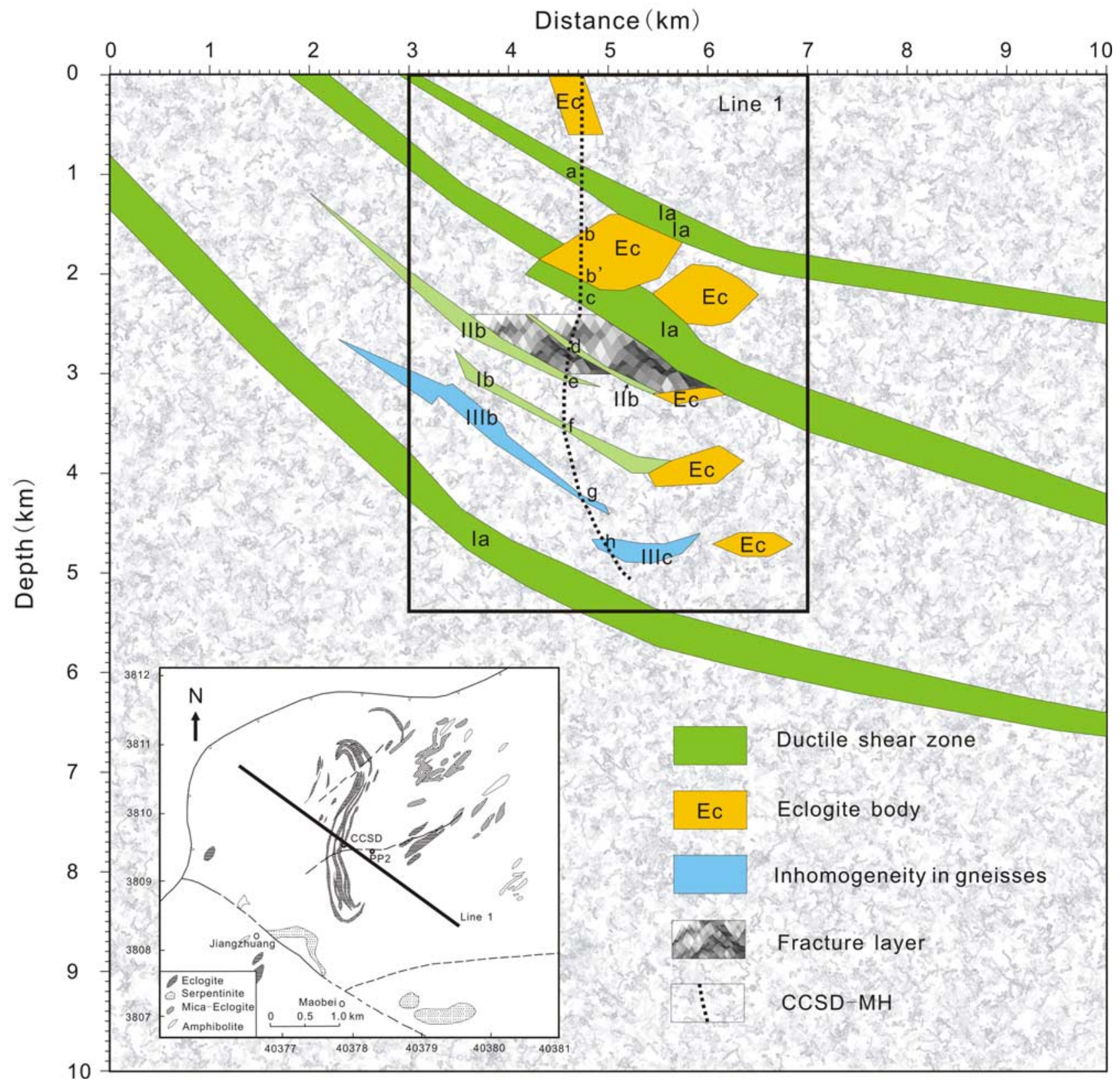

Figure 10. Two-dimensional model used in numerical simulation. The geological structure within the black box is inferred from seismic profile line 1 [Yang et al., 2006b]. The structure outside the black box is extrapolated by the authors. Letters a-h denote the numbers of main seismic reflectors of which the geological interpretation, and the thermal physical properties are given in Table 4.

may have been derived from different parts of the subducted crust during one or two phases of exhumation. The characteristics of the variation of the heat production with depth in these two sections are consistent in general with the hypothesis of You et al. [2004].

[42] Above $1650 \mathrm{~m}$, eclogites occur mainly between 100 and $600 \mathrm{~m}$, most of which are rutile-eclogite with high $\mathrm{Ti}$ or Ti-Fe [Zhang et al., 2004] and retrograde metamorphic eclogites. Their average heat production is about $0.53 \mu \mathrm{Wm}^{-3}$. The eclogites between 1650 and $2000 \mathrm{~m}$ are typically phengite-eclogite with high Al [Zhang et al., 2004], of which the $\mathrm{Pb}$ isotope signatures are also different from those of the shallower eclogites [Dong et al., 2006]. Their radiogenic heat production is only $0.26 \mu \mathrm{Wm}^{-3}$.

[43] Geochemical evidence indicates that different from the UHPM orthogneiss shallower than $1650 \mathrm{~m}$, the orthogneiss samples from the depth interval between 3470 and $5000 \mathrm{~m}$ are of normal $\mathrm{O}$ isotopic values with no evidence of UHP metamorphism [Zhang et al., 2006]. The orthogeiss rocks might have dived to depths greater than $100 \mathrm{~km}$ but, due to the lack of metamorphic fluid, have not turned into UHPM rocks [Zhang et al., 2006]. Their measured heat production is $1.92 \mu \mathrm{W} \mathrm{m} \mathrm{m}^{-3}$, higher than the value of 
Table 4. Thermal Properties Used in the Two-Dimensional Model

\begin{tabular}{|c|c|c|c|}
\hline Seismic Reflector ${ }^{\mathrm{a}}$ & Geological Interpretation $^{\mathrm{a}}$ & $\lambda, \mathrm{W} \mathrm{m} \mathrm{m}^{-1} \mathrm{~K}^{-1}$ & $A, \mu \mathrm{W} \mathrm{m}^{-3}$ \\
\hline a & ductile shear zone (Ia) & $2.2 / 3.6^{\mathrm{b}}$ & 1.0 \\
\hline $\mathrm{b}, \mathrm{b}^{\prime}$ & eclogite body (IIa) & 2.6 & 0.5 \\
\hline $\mathrm{c}$ & ductile shear zone (Ia) & $2.2 / 3.6^{\mathrm{b}}$ & 1.0 \\
\hline $\mathrm{d}$ & eclogite body (IIb) & 2.6 & 1.0 \\
\hline $\mathrm{e}$ & eclogite body (IIb) & 2.4 & 0.5 \\
\hline $\mathrm{f}$ & inhomogeneity in gneisses(Ib) & 2.7 & 2.5 \\
\hline $\mathrm{g}$ & inhomogeneity in gneisses(IIb) & 2.9 & 1.4 \\
\hline \multirow[t]{4}{*}{$\mathrm{h}$} & inhomogeneity in gneisses(IIIc) & 3.1 & 2.2 \\
\hline & outcrop eclogite & 3.1 & 0.5 \\
\hline & fracture zone & 2.6 & 1.3 \\
\hline & background gneiss & 2.8 & 1.5 \\
\hline
\end{tabular}

${ }^{\mathrm{a}}$ Based on the work by Yang et al. [2006b]

${ }^{b}$ Values for the upper and the lower parts of the ductile shear zone, respectively.

the orthogneiss $1.55 \mu \mathrm{Wm}^{-3}$ in the shallow part of the borehole.

\section{Heat Flow}

[44] We calculated heat flow values at CCSD MH by multiplying temperature gradients from the estimated equilibrium temperatures (Figure $6 \mathrm{~g}$ ) with thermal conductivities for different intervals (Figure 7b) [Powell et al., 1988]. The resultant heat flow-depth profiles are shown in Figure $7 \mathrm{~d}$. In general, the heat flow decreases with depth from $\sim 75 \mathrm{~mW} \mathrm{~m}^{-2}$ near the surface to $\sim 66 \mathrm{~mW} \mathrm{~m}^{-2}$ at the depth of $4600 \mathrm{~m}$. High heat flow anomalies occur at $\sim 1000$ and $\sim 2300 \mathrm{~m}$, and low anomalies occur at 3300-4000 m.

\subsection{Vertical Variation of Heat Flow}

[45] Generally, heat flow decreases with depth due to the contribution of radiogenic heat production of the rocks. The average radiogenic heat production over the depth range of CCSD MH is $1.23 \mu \mathrm{W} \mathrm{m}{ }^{-3}$, of which the contribution to the surface heat flow is about $6 \mathrm{~mW} \mathrm{~m} \mathrm{~m}^{-2}$. Over a half of the variation in the heat flow from the top to the bottom of CCSD MH can be accounted for by the measured heat generation over the 5-km depth interval. However, the vertical variation of the observed heat flow in CCSD MH is not monotonic. Other factors such as paleoclimate change [Wang and Lewis, 1992; Huang et al., 1997; Pollack and Huang, 2000] and heterogeneity in the subsurface [Clauser et al., 1997] must contribute to the variation.

[46] On the basis of seismic tomography analysis, Yang et al. [2006b] proposed that ductile shear zones are widely developed in the Donghai area. Three major ductile shear zones with dip angles of $25-30^{\circ}$ have been recognized by a seismic survey conducted in the Donghai area [Yang et al., 2006b]. Two of them are intercepted by CCSD MH at the depths of 900-1120 $\mathrm{m}$ and 2050-2300 m, corresponding to the heat flow anomalies at $\sim 1000 \mathrm{~m}$ and $\sim 2300 \mathrm{~m}$, respectively. They are mainly composed of mylonite and sandwiched thin eclogite and gneiss.

[47] On the basis of geological interpretations of the seismic reflectors from the survey [Yang et al., 2006b], we conduct a numerical experiment to evaluate the potential effects of thermal refraction on the vertical variation of heat flow. Our model spans $10 \mathrm{~km}$ in both the horizontal and vertical directions (Figure 10). The two-dimensional experiment is performed using the finite element method [Zhang and Xiong, 1986]. The grids are $20 \mathrm{~m} \times 50 \mathrm{~m}$ in the vicinity of the hole, and become coarser away from the hole with $500 \mathrm{~m} \times 500 \mathrm{~m}$ near the two vertical boundaries. The upper boundary of the model is set to have a constant temperature of $16^{\circ} \mathrm{C}$, and different constant basal heat flow values over the range from 50 to $70 \mathrm{mWm}^{-2}$ are used for different numerical tests. The thermal conductivities and radiogenic heat productions used in this model are given in Table 4.

[48] The maximum heat flows for the two shear zones at depth intervals of $900-1120 \mathrm{~m}$ and $2050-2300 \mathrm{~m}$ are both about $90 \mathrm{~mW} \mathrm{~m} \mathrm{~m}^{-2}$. The mean conductivities of the two intervals are almost identical $\left(2.8\right.$ and $2.9 \mathrm{~W} \mathrm{~m}^{-1} \mathrm{~K}^{-1}$, respectively). However, the thermal conductivities within each of these two zones vary greatly, ranging from 2.2 to $3.6 \mathrm{~W} \mathrm{~m}^{-1} \mathrm{~K}^{-1}$. These two zones also exhibit interbedded positive and negative anomalies in seismic velocity and density [Yang et al., 2006b]. Additionally, the positive heat flow anomalies at these two zones are capped by negative anomalies. In our 2-D model, therefore, we divide each ductile zone into upper and lower sublayers with a thermal conductivity contrast of $2.2 / 3.6 \mathrm{~W} \mathrm{~m}^{-1} \mathrm{~K}^{-1}$ (Table 4).

[49] A base heat flow value of $58 \mathrm{~mW} \mathrm{~m}^{-2}$ at the lower boundary was found to give the best match to the measured temperature and heat flow data from CCSD MH. The heat flow trend predicted by this conductive steady state model is generally consistent with the measurement from CCSD MH (Figure 11), although there are discrepancies in details. The discrepancies could be caused by several factors. As discussed in section 2.3, the borehole measurements comprise advective transient perturbations that cannot be explained by the model. Additionally there are large uncertainties in the 2-D model which is based on the preliminary seismic survey results [Yang et al., 2006b]. Moreover, the effect of paleoclimate change has not been taken into account at this stage. Nevertheless, the current 2-D model indicates that, besides the radiogenic heat production, thermal refraction from the complex geological structure is another factor responsible for the variation of heat flow with depth in CCSD MH.

\subsection{Tectonic Implications}

[50] The surface heat flow from CCSD MH is close to those measured in CCSD PP1 and CCSD PP2, which are 76 and $80 \mathrm{~mW} \mathrm{~m}^{-2}$, respectively [Wang et al., 2001a]. The heat flow measurements of CCSD indicate a heat flow in the Dabie-Sulu UHPM belt higher than the mean value $61 \mathrm{~mW} \mathrm{~m}^{-2}$ from the continental area of China [Hu et al., 


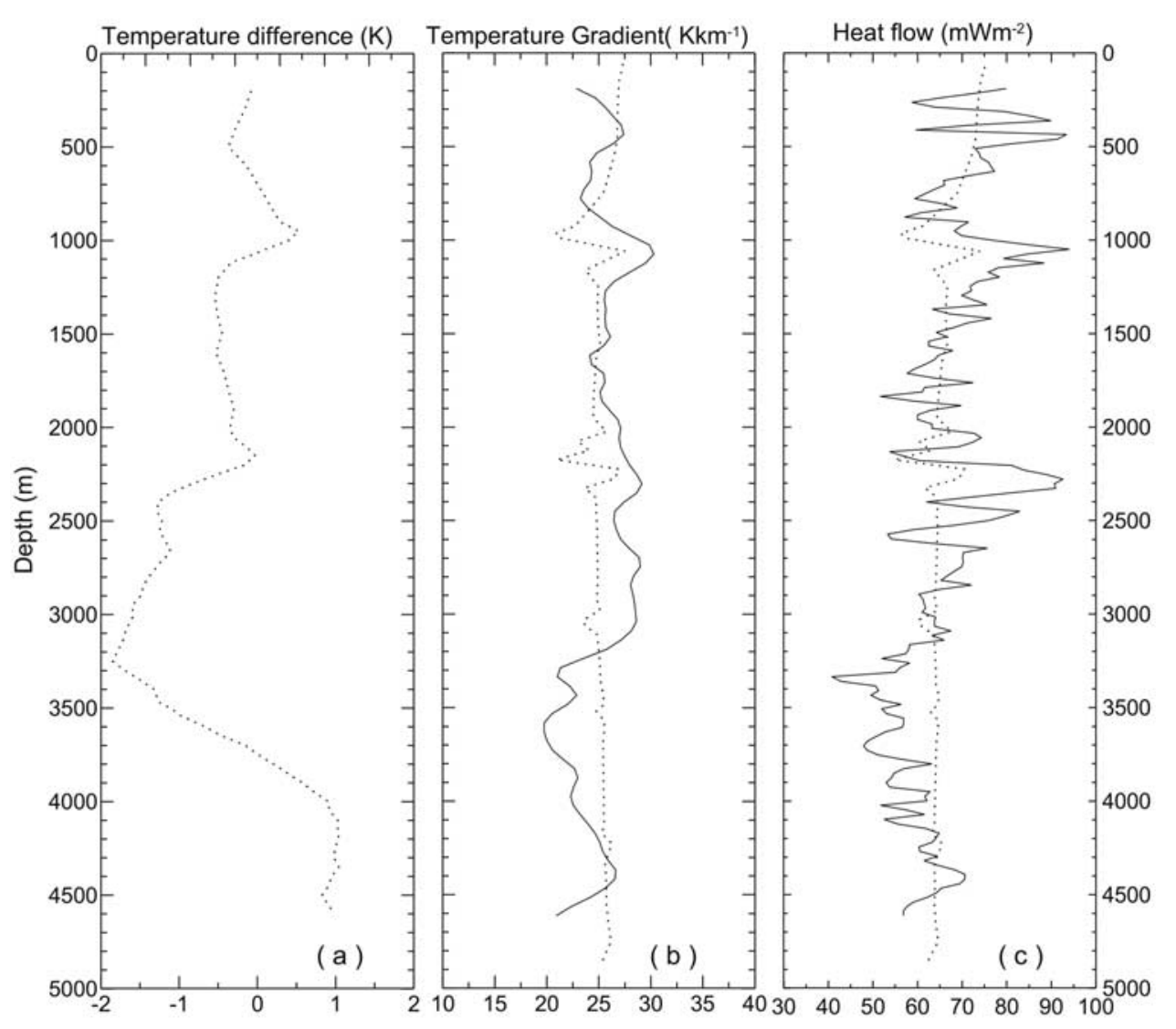

Figure 11. Model predicted values versus measurements: (a) temperature difference between prediction and measurement; (b) temperature gradient; and (c) heat flow. The solid line represents the measured values.

2000], as well as its adjacent cratons. The mean heat flow is $50 \mathrm{~mW} \mathrm{~m}^{-2}$ for the North China Craton to its north, and $53 \mathrm{~mW} \mathrm{~m}{ }^{-2}$ for the Yangtze Craton to its south. The heat flow of the Dabie-Sulu UHPM belt is close to those in the two Cenozoic extensional basins in the nearby cratons, the Bohai Bay Basin and the Subei Basin, which are 69 and $72 \mathrm{~mW} \mathrm{~m}^{-2}$, respectively.

[51] The relatively high heat flow of the Dabie-Sulu UHPM belt must be attributable to the tectonic activities after the Triassic collision between the North China and Yangtze cratons in this area. In the Triassic, the subduction of the Yangtze continental crust occurred, and was followed by slab break-off and the initial uplift of UHPM rocks from mantle depths to midcrustal levels [Sun et al., 2002]. Paleomagnetic studies suggest that the convergence between the North China and Yangtze cratons continued after break-off of the subducted plate [Zhao and Coe, 1987]. In the mid-Jurassic, the continuous convergence between the North China and Yangtze cratons created an over-thickened lithosphere in the Dabie-Sulu orogen and southern margin of the North China Craton. The appearance of garnet and loss of plagioclase in the deeply subducted mafic lower crust or lower part of thickened mafic lower crust resulted in a gravitational instability and negative buoyancy in the keel of the thickened lithosphere. The mafic lower continental (eclogitic) crust and lithospheric mantle of the Yangtze Craton (with a density up to $3.8 \mathrm{~g} \mathrm{~cm}^{-1}$ ) would detach and founder into the upper mantle in the early Cretaceous
[Huang et al., 2007]. The hot asthenosphere upwelled leading to lithospheric extension and thinning, and consequently increasing heat flow. In the extensional environment in the early Cretaceous, the upwelling metasomatised mantle was partially melted due to decompression to produce the parental magma of the postcollisional mafic-ultramafic intrusive rocks [Huang et al., 2007]. The mass transfer of the magmatism must be accompanied by excessive heat transfer within the lithosphere.

[52] Therefore, two tectonic processes must have contributed to the relatively high heat flow of the Dabie-Sulu UHPM belt. The continental collision between the North China Craton and the Yangtze Craton should result in a higher crustal heat flow due to the over-thickened lithosphere, and consequentially extra amount of radiogenic heat producing elements at greater depths. Another process is the postcollision delamination and magmatism in this region, which resulted in higher mantle heat flow. The measured heat flow from the CCSD boreholes is consistent with the thermotectonic history of the Dabie-Sulu UHPM belt.

\section{Comparison With Other Deep Boreholes}

[53] There are only a few deep scientific boreholes penetrating into the crystalline basement in the world. The Kola superdeep well SG-3 is as of now the deepest one, which reaches a depth of $12,262 \mathrm{~m}$. The main hole of the German Continental Deep Drilling Program (KTB HB), 
Table 5. Comparison of Some Key Parameters of CCSD MH, Kola SG-3, and KTB HB

\begin{tabular}{|c|c|c|c|}
\hline \multirow[b]{2}{*}{ Parameter } & \multicolumn{3}{|c|}{ Deep Borehole } \\
\hline & CCSD MH & Kola SG-3 & КТВ НB \\
\hline Location & $34^{\circ} 24^{\prime} 36^{\prime \prime} \mathrm{N}, 118^{\circ} 40^{\prime} 12^{\prime \prime} \mathrm{E}$ & $69^{\circ} 25^{\prime} \mathrm{N}, 30^{\circ} 44^{\prime} \mathrm{E}$ & $49^{\circ} 48^{\prime} 58.8^{\prime \prime} \mathrm{N}, 12^{\circ} 7^{\prime} 19.2^{\prime \prime} \mathrm{E}$ \\
\hline Site & Dabie-Sulu UHPM Belt & the Baltic Shield & the Hercynian ZEV \\
\hline Drilling period & 4 Aug 2001 to 8 Mar 2005 & 25 May 1970 to 19 Aug 1991 & 6 Oct 1990 to 12 Oct 1994 \\
\hline Depth, m & 5,158 & 12,262 & 9,101 \\
\hline Thermal gradient, $\mathrm{K} \mathrm{km}^{-1}$ & 25.4 & $11-24$ & 27.5 \\
\hline Thermal conductivity, $\mathrm{W} \mathrm{m} \mathrm{m}^{-1} \mathrm{~K}^{-1}$ & $\begin{array}{l}\text { gneiss, } 2.8 \pm 0.34 ; \text { amphibolite, } \\
2.37 \pm 0.37\end{array}$ & $\begin{array}{l}\text { gneiss, } 2.46 \pm 0.38 ; \text { amphibolite, } \\
\quad 2.39 \pm 0.32\end{array}$ & $\begin{array}{l}\text { gneiss, } 3.0 \pm 0.5 ; \text { metabasite, } \\
\quad 2.6 \pm 0.5\end{array}$ \\
\hline Heat production rate, $\mu \mathrm{W} \mathrm{m}{ }^{-3}$ & $\begin{array}{l}\text { gneiss, } 1.5 \pm 0.7 ; \text { amphibolite, } \\
\quad 0.6 \pm 0.6\end{array}$ & gneiss, 1.4 & $\begin{array}{l}\text { gneiss, } 1.6 \pm 0.3 \text {; metabasite, } \\
\quad 0.5 \pm 0.4\end{array}$ \\
\hline Heat flow, $\mathrm{mW} \mathrm{m}^{-2}$ & 75/66(surface/bottom) & 35/51(surface/bottom) & 85(average) \\
\hline
\end{tabular}

with a depth of $9101 \mathrm{~m}$, is another well-known deep borehole dedicated for scientific research. Summarized in Table 5 are some parameters of CCSD MH, Kola SG-3 and KTB HB for comparison. The thermal properties (thermal conductivity and heat production) of the main rocks (gneiss and amphibolite) revealed by the three wells are rather consistent.

[54] The deep boreholes allow examinations of the vertical distribution of the radiogenic heat production in the upper crust. All the three deep holes indicate that the radiogenic heat production is strongly correlated with lithology and does not decrease exponentially with depth [Arshavskaya et al., 1987; Pribnow and Winter, 1997].

[55] In all these three deep boreholes, heat flow varies with depth in a complex fashion. An important characteristic of Kola SG-3 is that heat flow increases with depth from around $35 \mathrm{~mW} \mathrm{~m}^{-2}$ near the surface to over $75 \mathrm{~mW} \mathrm{~m}^{-2}$ at the depth of about $4.8 \mathrm{~km}$ and decreases in the lower part [Popov et al., 1999b]. The increase in heat flow in the upper part of SG-3 is mainly due to advection, because of the topographic driven flow [Mottaghya et al., 2005].

[56] In contrast, the main cause for the vertical variations of heat flow in KTB HB is the steep inclination and folding combined with heterogeneity and contrasts in thermal conductivity [Clauser et al., 1997]. Low values of around $50-60 \mathrm{~mW} \mathrm{~m}^{-2}$ occur in the upper $500 \mathrm{~m}$. It increases to $80-90 \mathrm{~mW} \mathrm{~m} \mathrm{~m}^{-2}$ at about $3000 \mathrm{~m}$. Then, it shows a pronounced change to lower values around $3000 \mathrm{~m}$ before increasing with depth again. Advective heat transfer is only confined to the top 500-1000 $\mathrm{m}$ around KTB. The mean heat flow of KTB super deep borehole is $85 \mathrm{~mW} \mathrm{~m}^{-2}$ [Clauser et al., 1997].

[57] Different from the above two deep boreholes, the heat flow at CCSD MH shows a generally decreasing trend with depth. As illustrated by the two-dimensional numerical modeling, the general decreasing of surface heat flow can at least partially be attributed to the radiogenic heat production and the thermal refraction from the complex geological structure. Some abrupt changes in the heat flow of CCSD $\mathrm{MH}$ are probably due to the transient effect of fluids associated with fractures.

\section{Conclusions}

[58] To date we have obtained six repeat temperature logs from CCSD MH. The mean observed temperature gradient in CCSD MH increased progressively from $24.38 \mathrm{~K} \mathrm{~km}^{-1}$ of the first $\log$ of 2 April 2005 to $25.28 \mathrm{~K} \mathrm{~km}^{-1}$ of the sixth $\log$ of 23 September 2006. The ongoing thermal recovery from the disturbances of drilling fluid circulation is reflected not only in changes in the mean temperature gradient, but also in changes in the mean standard deviation which decreased from $5.02 \mathrm{~K} \mathrm{~km}^{-1}$ of the first $\log$ to $2.85 \mathrm{~K} \mathrm{~km}^{-1}$ of the sixth $\log$.

[59] The repeat temperature logs allow inference of equilibrium borehole temperatures. On the basis of the logarithmic method developed by Lachenbruch and Brewer [1959], the mean equilibrium temperature gradient of CCSD MH is estimated to be $25.31 \mathrm{~K} \mathrm{~km}^{-1}$. The inferred equilibrium temperature profile projects a temperature of about $142^{\circ} \mathrm{C}$ at the depth of $5000 \mathrm{~m}$.

[60] Thermal conductivity measurements have been made on 198 core samples with a sampling depth interval of $\sim 25 \mathrm{~m}$. The measured thermal conductivities range between 1.71 and $3.60 \mathrm{~W} \mathrm{~m}^{-1} \mathrm{~K}^{-1}$. Mean values for different rock types are not vastly different, for example $2.37 \pm 0.37 \mathrm{~W}$ $\mathrm{m}^{-1} \mathrm{~K}^{-1}$ for amphibolite and $2.97 \pm 0.33 \mathrm{~W} \mathrm{~m}^{-1} \mathrm{~K}^{-1}$ for serpentinite.

[61] The heat production values of the core samples from CCSD MH vary dramatically from the lowest mean $0.01 \mu \mathrm{W} \mathrm{m}^{-3}$ for peridotite to the highest mean $1.65 \mu \mathrm{W}$ $\mathrm{m}^{-3}$ for orthogneiss. The radiogenic heat productions of the metamorphic rocks in the uppermost crust of the Dabie-Sulu UHPM Belt are substantially lower than that of their protoliths. The average radiogenic heat production of the 255 CCSD MH core samples is $1.23 \mu \mathrm{W} \mathrm{m}^{-3}$, as opposed to the mean of $1.96 \mu \mathrm{W} \mathrm{m}^{-3}$ of the Yangtze Craton [Wang et al., 1989]. The different heat productions between the metamorphic rocks and their protoliths suggest depletion of uranium due to ultrahigh-pressure metamorphism. The radiogenic heat productions from CCSD MH do not fit the model of exponential decrease with increasing depth [Lachenbruch, 1968, 1970]. The vertical variation of the heat production in the Dabie-Sulu UHPM belt depends mainly on lithology.

[62] The measured heat flow at CCSD MH decreases generally from around $75 \mathrm{~mW} \mathrm{~m}{ }^{-2}$ near the surface to $66 \mathrm{~mW} \mathrm{~m}^{-2}$ near the bottom of the borehole. A preliminary two-dimensional model shows that, besides the radiogenic heat production, thermal refraction from the complex geological structure is another factor responsible for the variation of heat flow with depth in CCSD MH. The possible effect of paleoclimate change is yet to be investigated. 
[63] High heat flow anomalies occur at $\sim 1000 \mathrm{~m}$ and $\sim 2300 \mathrm{~m}$, and low anomalies at 3300-4000 $\mathrm{m}$. These and other abrupt anomalies appear to be shrinking with time. They are likely caused by transient perturbations associated with fractures that accept circulation fluid during drilling but do not permit fluid flow before and after drilling [Lewis and Beck, 1977; Drury and Jessop, 1982; Drury et al., 1984; Beck and Balling, 1988].

[64] The measurement from CCSD MH and those from CCSD PP1 and CCSD PP2 [Wang et al., 2001a] show that heat flow in the Dabie-Sulu UHPM belt is higher than its adjacent areas. The mean surface heat flow of the three boreholes at the CCSD site is $77 \mathrm{~mW} \mathrm{~m}^{-2}$, as opposed to the mean of $50 \mathrm{~mW} \mathrm{~m}{ }^{-2}$ for North China Craton to its north, $53 \mathrm{~mW} \mathrm{~m}^{-2}$ for the Yangtze Craton to its south, and $61 \mathrm{~mW} \mathrm{~m}^{-2}$ for the overall continental area of China [Hu et $a l ., 2000]$. Two tectonic processes must have contributed to the relatively high heat flow of the Dabie-Sulu UHPM belt. The continental collision between the North China Craton and the Yangtze Craton [Li et al., 1989b] would result in a higher crustal heat flow due to the over-thickened lithosphere, and consequentially extra amount of radiogenic heat producing elements at greater depths. Another process is the postcollision delamination and magmatism in this region. The measured heat flow from the CCSD boreholes is consistent with the thermotectonic history of the DabieSulu UHPM belt.

[65] Acknowledgments. We thank Jin Zhen Min for providing the rock density data used in the heat production calculation. Special thanks are due to Trevor Lewis, Jean-Claude Mareschal, and Kelin Wang, who thoroughly reviewed the paper and substantially improved the manuscript by their critical remarks and helpful suggestions. This work was supported by the Chinese National Key Basic R\&D Program 973 (2003CB716505, 2006CB202206). The concentrations of the heat-producing elements were determined in the Analysis Testing Research Center of Nuclear Industrial Geology, Beijing, China.

\section{References}

Arshavskaya, N. I., N. E. Galdin, E. W. Karus, O. L. Kuznetsov, E. A. Lubimova, S. Y. Milanovsky, V. D. Nartikoev, S. A. Semashko, and E. V. Smirnova (1987), Geothermic investigations, in The Superdeep Well of the Kola Peninsula, edited by Y. A. Kozlovsky, pp. 387-393, Springer, New York.

Ashwal, L. D., P. Morgan, S. A. Kelley, and J. A. Percival (1987), Heat production in an Archean crustal profile and implications for heat flow and mobilization of heat-producing elements, Earth Planet. Sci. Lett., 85, $439-450$.

Beck, A. E., and N. Balling (1988), Determination of virgin rock temperatures, in Handbook of Terrestrial Heat-Flow Density Determination, edited by Haenel, R., et al., pp. 59-85, Kluwer Acad., Dordrecht, Netherlands.

Birch, F., and H. Clark (1940), The thermal conductivity of rocks and its dependence upon temperature and composition, Am, J. Sci., 238, 529558, 613-635.

Brady, R. J., M. N. Ducea, S. B. Kidder, and J. B. Saleeby (2006), The distribution of radiogenic heat production as a function of depth in the Sierra Nevada Batholith, California, Lithos, 86(3-4), 229-244.

Bullard, E. C. (1947), The time necessary for a borehole to attain temperature equilibrium, Mon. Not. R. Astron. Soc., Geophys. Suppl., 5, 127-130.

Chi, Q. H., and M. C. Yan (1998), Radioactive elements of rocks in North China Platform and the thermal structure and temperature distribution of the modern continental lithosphere, Chin. J. Geophys., 41, 38-48.

Clauser, C., P. Giese, E. Huenges, T. Kohl, H. Lehmann, L. Rybach, J. Safanda, H. Wilhelm, K. Windloff, and G. Zoth (1997), The thermal regime of the crystalline continental crust: Implication from the KTB, J. Geophys. Res., 102, 18,417-18,441.

Cui, J. W., L. J. Wang, P. W. Li, D. H. Xu, and H. Y. Wu (2004), Tectonic stress field of brittle deformation within $2000 \mathrm{~m}$ of the main borehole Chinese Continental Scientific Drilling (in Chinese with English abstract), Acta Petrol. Sin., 20(1), 73-80.
Dong, F., S. Li, Q. Li, Y. Liu, and F. Chen (2006), Preliminary study of common $\mathrm{Pb}$ of UHP metamorphic rocks from CCSD $(100-2000 \mathrm{~m})$ : Evidence for decoupling within subducting continental crust (in Chinese with English abstract), Acta Petrol. Sin., 22(7), 1791-1798.

Drury, M. J., and A. M. Jessop (1982), The effect of a fluid-filled fracture on the temperature profile in a borehole, Geothermics, 11(3), 145-152.

Drury, M. J., A. M. Jessop, and T. J. Lewis (1984), The detection of groundwater flow by precise temperature measurements in boreholes, Geothermics, 13(3), 163-174.

Gao, S., B. Zhang, and Z. Jin (1999), Lower crustal delamination in the Qinling-Dabie orogenic belt, Sci. China, Ser. D, 42, 423-443.

Gao, S., R. L. Rudnick, H. Yuan, X. Liu, Y. Liu, W. Xu, W. Ling, J. Ayers, X. Wang, and Q. Wang (2004), Recycling lower continental crust in the north China craton, Nature, 432, 892-897.

Hacker, B. R., L. Ratschbacher, L. E. Webb, M. McWilliams, T. Ireland, A. Calvert, S. Dong, H. R. Wenk, and D. Chateigner (2000), Exhumation of the ultrahigh-pressure continental crust in east central China: Late Triassic-Early Jurassic extension, J. Geophys. Res., 105, 13,339-13,364.

Hart, R. J., L. O. Nicolaysen, and N. H. Gale (1981), Radioelement concentrations in a deep profile through Archean basement of the Vredefort structure, J. Geophys. Res., 86, 10,639-10,652.

He, L., S. Hu, W. Yang, J. Wang, S. Yang, Y. Yuan, and Z. Chen (2006), Temperature measurement in the main hole of the Chinese Continental Scientific Drilling, Chin. J. Geophys., 49, 671-678.

$\mathrm{Hu}, \mathrm{S}$., L. He, and J. Wang (2000), Heat flow in the continental area of China: A new data set, Earth Planet. Sci. Lett., 179, 407-419.

Hu, S., M. Fu, S. Yang, Y. Yuan, and J. Wang (2007), Palaeogeothermal response and record of the Late Mesozoic lithospheric thinning in eastern North China Craton, in Mesozoic Sub-continental Lithospheric Thinning Under Eastern Asia, edited by M. Zhai et al., Geol. Soc. Spec. Publ., 280, $267-280$

Huang, F., F. Li, Q. Li, F. Chen, Y. Wang, and W. Yang (2007), Recycling of deeply subducted continental crust in the Dabie Mountains, central China, Lithos, 96, 151-169.

Huang, S. P., H. N. Pollack, and P. Y. Shen (1997), Late Quaternary temperature changes seen in world-wide continental heat flow measurements, Geophys. Res. Lett., 24, 1947-1950.

Jaupart, C., and J. C. Mareschal (2003), Constraints on crustal heat production from heat flow data, Treatise on Geochemistry, vol.3, The Crust, edited by R. Rudnick, pp. 65-84, Elsevier, New York.

Ketcham, R. A. (1996), Distribution of heat-producing elements in the upper and middle crust of southern and western Arizona: Evidence from the core complexes, J. Geophys. Res., 101, 13,611-13,632.

Kremenetsky, A. A., S. Y. U. Milanovsky, and L. N. Ovchinnikov (1989), A heat generation model for continental crust based on deep drilling in the Baltic Shield, Tectonophysics, 159, 231-246.

Lachenbruch, A. H. (1968), Preliminary geothermal model of the Sierra Nevada, J. Geophys. Res., 73, 6977-6989.

Lachenbruch, A. H. (1970), Crustal temperature and heat production: Implications of linear heat-flow relation, J. Geophys. Res., 75, 32913300 .

Lachenbruch, A. H., and M. C. Brewer (1959), Dissipation of the temperature effect of drilling a well in Arctic Alaska, U. S. Geol. Surv. Bull., $1083 C, 73-109$.

Lewis, T. J., and A. E. Beck (1977), Analysis of heat flow data: Detailed observations in many holes in a small area, Tectonophysics, 41, 41-59.

Li, S., S. Hart, S. Zheng, D. Liu, G. Zhang, and A. Guo (1989a), Timing of collision between the north and south China blocks-The Sm-Nd isotopic age evidence, Sci. China, 32, 1393-1400.

Li, S., S. Hart, S. Zheng, D. Liu, G. Zhang, and A. Guo (1989b), Timing of collision between the north and south China blocks-The Sm-Nd isotopic age evidence, Sci. China, 32, 1393-1400.

Liu, F., Z. Xu, and H. Xue (2004), Tracing the protolith, UHP metamorphism, and exhumation ages of orthogneiss from the SW Sulu terrane (eastern China): SHRIMP U-Pb dating of mineral inclusion-bearing zircons, Lithos, 78, 411-429.

Liu, F. L., Z. Q. Xu, H. M. Xue, and F. C. Meng (2005a), Ultrahighpressure mineral inclusions preserved in zircons separated from ecolgites and its country-rocks in the main drill hole of Chinese Continental Scientific Drilling Project $(0-4500 \mathrm{~m})$ (in Chinese with English abstract), Acta Petrol. Sin., 21(2), 277-292.

Liu, F. L., Z. Q. Xu, J. S. Yang, Z. M. Zhang, H. M. Xue, F. C. Meng, T. F. $\mathrm{Li}$, and S. Z. Chen (2005b), Geochemical characteristics and genetic mechanism of orthogneiss and paragneiss in the depth interval of 2000-3000 m from main drill hole of Chinese Continental Scientific Drilling Project (in Chinese with English abstract), Acta Petrol. Sin., 21(2), 305-324.

Luo, L. Q., Q. Sun, and X. C. Zhan (2004), 0-2000m fluid profiles and sources in the Chinese Continental Scientific Drilling Project (in Chinese with English abstract), Acta Petrol. Sin., 20(1), 185-191. 
Mottaghya, D., T. R. Schellschmidtb, Y. A. Popovc, C. Clausera, I. T. Kukkonend, G. Novere, S. Milanovskyf, and R. A. Romushkevich (2005), New heat flow data from the immediate vicinity of the Kola super-deep borehole: Vertical variation in heat flow confirmed and attributed to advection, Tectonophysics, 401, 119-142.

Nicolaysen, L. O., R. J. Hart, and N. H. Gale (1981), The Vredefort radioelement profile extended to supracrustal strata at Carletonville, with implications for continental heat flow, J. Geophys. Res., 86, 10,65310,661 .

Nielsen, S. B. (1986), The continuous temperature log: Method and applications, Ph.D. thesis, 200 pp, Univ. of West. Ont., London, Canada.

Nielsen, S. B., and N. Balling (1984), Accuracy and resolution in continuous temperature logging, Tectonophysics, 103, 1-10.

Niu, Y., H. Pan, and W. Wang (2004), Geophysical well logging in main hole $(0-2000 \mathrm{~m})$ of Chinese Continental Scientific Drilling (in Chinese with English abstract), Acta Petrol. Sin., 20(1), 165-178.

Ou, X., Z. Jin, L. Wang, H. Xu, and S. Jin (2004), Thermal conductivity and its anisotropy of rocks from the depth of 100-2000 m main hole of Chinese continental scientific drilling: Relations to the study on thermal structure of subduction zone (in Chinese with English abstract), Acta Petrol. Sin., 20(1), 109-118

Pan, H., Y. Niu, W. Wang, L. Zhu, D. Xu, and S. Li (2006), Joint interpretation of reflections via well logging and seismic data in the Pilot hole of CCSD (in Chinese with English abstract), Earth Sci. J. China Univ. Geosci., 31, 569-574.

Pollack, H. N., and S. P. Huang (2000), Climate reconstruction from subsurface temperatures, Annu. Rev. Earth Planet. Sci., 28, 339-365.

Popov, Y. A., D. F. C. Pribnow, J. H. Sass, C. F. Williams, and H. Burkhardt (1999a), Characterization of rock thermal conductivity by high-resolution optical scanning, Geothermics, 28, 253-276.

Popov, Y. A., S. L. Pevzner, V. P. Pimenov, and R. A. Romushkevich (1999b), New geothermal data from the Kola superdeep well SG-3, Tectonophysics, 306, 345-366.

Powell, W. G., D. S. Chapman, N. Balling, and A. E. Beck (1988), Continental heat-flow density, in Handbook of Terrestrial Heat-Flow Density Determination, edited by R. Haenel et al., pp. 167-218, Kluwer Acad., Dordrecht, Netherlands.

Pribnow, D. F. C., and H. R. Winter (1997), Radiogenic heat production in the upper third of continental crust from KTB, Geophys. Res. Lett., 24(3), 349-352.

Pribnow, D., C. F. Williams, J. H. Sass, and R. Keating (1996), Thermal conductivity of water-saturated rocks from the KTB pilot hole at temperatures of 25 to $300^{\circ}$ C, Geophys. Res. Lett., 23(4), 391-394.

Ratschbacher, L., B. R. Hacker, L. E. Webb, M. McWilliams, T. Ireland, S. Dong, A. Calvert, D. Chateigner, and H. R. Wenk (2000), Exhumation of the ultrahigh-pressure continental crust in east-central China: Cretaceous and Cenozoic unroofing and the Tan-Lu fault, J. Geophys. Res., 105, 13,303-13,338.

Reiter, M., A. J. Mansure, and B. K. Peterson (1980), Precision continuous temperature logging and comparison with other types of logs, Geophysics, 45(12), 1857-1868

Rybach, L. (1988), Determination of heat production rate, in Handbook of Terrestrial Heat Flow Density Determination, edited by R. Haenel et al., pp. 125-142, Kluwer Acad., Dordrecht, Netherlands.

Rybach, L., and G. Buntebarth (1982), Relationships between the petrophysical properties, density, seismic velocity, heat generation and mineralogical constitution, Earth Planet. Sci. Lett., 57, 367-376.

Sass, J. H., A. H. Lachenbruch, T. H. Moses, and P. Morgan (1992), Heat flow from a scientific research well at Cajon pass, California, J. Geophys Res., 97, 5017-5030.

Seipold, U., and E. Huenges (1998), Thermal properties of gneisses and amphibolites-high pressure and high temperature investigations of KTBrock samples, Tectonophysics, 291, 173-178.

Sun, Q., L. Q. Luo, and S. Li (2004), N2-Ar-He compositions in the 0 $2000 \mathrm{~m}$ mud of Chinese Continental Scientific Drilling hole (in Chinese with English abstract), Acta Petrol. Sin., 20(1), 179-184.

Sun, W. D., I. S. Williams, and S. G. Li (2002), Carboniferous and Triassic eclogite in the western Dabie mountains, east-central China: Evidence for protracted convergence of the North and South China blocks., J. Metamorph. Geol., 20,873-886.

Swanberg, C. A. (1972), Vertical distribution of heat production in the Idaho batholith, J. Geophys. Res., 77, 2508-2513.

Swanberg, C. A., and D. D. Blackwell (1973), Areal distribution and geophysical significance of heat generation in the Idaho batholith and adjacent intrusions in eastern Oregon and western Montana, Geol. Soc. Am. Bull., 84, 1261-1282.
Tang, Z. M. (2005), Attitude characteristics of ecologite type and gneiss type foliations and miniature faults in 100-2950m core of the CCSD main hole (in Chinese with English abstract), Acta Petrol. Mineral., 24(5), 439-442.

Verdoya, M., V. Pasquale, P. Chiozzi, and I. T. Kukkonen (1998), Radiogenic heat production in the Variscan crust: New determinations and distribution models in Corsica (northwestern Mediterranean), Tectonophysics, 291, 63-75

Wang, J. Y., S. Hu, W. Yang, B. Cheng, Z. Cheng, and T. Li (2001a), Geothermal measurements in the pilot-boreholes of the China Continental Scientific Drilling, Chin. Sci. Bull., 46, 1745-1748.

Wang, J. Y., S. B. Hu, B. H. Cheng, T. J. Li, W. C. Yang, and Z. Y. Cheng (2001b), Predication of the deep temperature in the target area of the Chine Continental Scientific Drilling, Chin. J. Geophys., 44, 774-782.

Wang, K., and T. J. Lewis (1992), Geothermal evidence from Canada for a cold period before recent climate warming, Sci. China, Ser. D, 256, $1003-1005$

Wang, X., J. G. Liou, and H. K. Mao (1989), Coesite-bearing eclogite from the Dabie Mountains, central China, Geology, 17, 1085-1088.

Wu, Y., Z. M. Jin, X. G. Ou, H. J. Xu, and L. Wang (2005), Lithospheric thermal structure beneath the area of the Chinese Continental Scientific Drilling Site (CCSD) (in Chinese with English abstract), Acta Petrol. Sin., 21, 439-450.

$\mathrm{Xu}, \mathrm{Z}$. (1987), Etude tectonique et microtectinique de la Chaine paleozoique de Qinlings, diplome de doctorat, pp. 93-107, Univ. des Sci. et Tech. du Languedoc, Montpellier, France.

Xu, Z., W. Yang, Z. Zhang, and T. Yang (1998), Scientific significance and site selection researches of the first Chinese Continental Scientific deep drill hole, Cont. Dyn., 3, 1-13.

$\mathrm{Xu}, \mathrm{Z}$. Q., et al. (2003), Exhumation structure and mechanism of the Sulu ultrahigh-pressure metamorphic belt, central China, Acta Geol. Sin., 77, $433-450$.

Xue, H. M., and F. L. Liu (2005), Geochemical characteristics and genesis of plagiogneiss from the $0-2000 \mathrm{~m}$ main hole of the Chinese Continental Scientific Drilling Project (in Chinese with English abstract), Acta Petrol. Sin., 21, 355-368

Yang, W. (2002), Geophysical profiling across the Sulu ultra-high-pressure metamorphic belt, east China, Tectonophysics, 354, 277-288.

Yang, W. C., G. Liu, K. Yang, and Z. Cheng (2006a), All-laid-out threedimensional seismic survey at the Chinese Continental Scientific Drilling site (in Chinese with English abstract), Chin. J. Geophys., 49(3), 735744

Yang, W. C., W. Y. Yang, and Z. Y. Cheng (2006b), Calibration of seismic reflectors at the Chinese Continental Scientific Drilling site (in Chinese with English abstract), Chin. J. Geophys., 49(6), 1682-1692.

Yin, A., and S. Nie (1996), A Phanerozoic palinspastic reconstruction of China and its neighboring regions, in The Tectonic Evolution of Asia, edited by A. Yin and T. M Harrison, pp. 442-485, Cambridge Univ. Press, New York.

You, Z. D., S. Su, F. Liang, and Z. Zhang (2004), Petrography and metamorphic deformational history of the ultrahigh-pressure metamorphic rocks from the 100-2000m core of Chinese Continental Scientific Drilling, China (in Chinese with English abstract), Acta Petrol. Sin., 20(1), $43-52$.

Zhang, J., and L. Xiong (1986), Application of the Finite Element Methods to Geothermal Research (in Chinese), 138 pp., Sci. Press, Beijing

Zhang, Z. M., Z. Q. Xu, F. L. Liu, Z. D. You, K. Shen, J. S. Yang, T. F. Li, and S. Z. Chen (2004), Geochemistry of eclogites from the main hole $(100-2050 \mathrm{~m})$ of the Chinese Continental Scientific Drilling site (in Chinese with English abstract), Acta Petrol. Sin., 20, 27-42.

Zhang, Z. M., Y. Xiao, X. Zhao, and C. Shi (2006), Fluid-rock interaction during the continental deep subduction: Oxygen isotopic profile of the main hole of the CCSD project (in Chinese with English abstract), Acta Petrol. Sin., 22(7), 1941-1951.

Zhao, X., and R. S. Coe (1987), Paleomagnetic constraints on the collision and rotation of north and south China, Nature, 327, 141-144.

L. He, S. Hu, J. Wang, Y. Yuan, and S. Yang, Institute of Geology and Geophysics, Chinese Academy of Sciences, Beijing 100029, China. (ljhe@mail.igcas.ac.cn)

S. Huang, Department of Geological Sciences, University of Michigan, Ann Arbor, MI 48109-1005, USA

W. Yang, Institute of Geology, Chinese Academy of Geological Sciences, Beijing 100037, China. 